\title{
Plants on the Move: Hitch-Hiking With Ungulates Distributes Diaspores Across Landscapes
}

\author{
Christophe Baltzinger ${ }^{1,2 *}$, Sorour Karimi ${ }^{1,3}$ and Ushma Shukla ${ }^{1}$ \\ ${ }^{1}$ Irstea, Research Unit Forest Ecosystems, Nogent-sur-Vernisson, France, ${ }^{2}$ Centre for Invasion Biology, School of Life \\ Sciences, University of KwaZulu-Natal, Pietermaritzburg, South Africa, ${ }^{3}$ Department of Natural Resources, Isfahan University \\ of Technology, Isfahan, Iran
}

OPEN ACCESS

Edited by:

Casper H. A. Van Leeuwen, Netherlands Institute of Ecology (NIOO-KNAW), Netherlands

Reviewed by: Lloyd W. Morrison, Missouri State University, United States Neil E. Coughlan, Queen's University Belfast, United Kingdom

*Correspondence:

Christophe Baltzinger christophe.baltzinger@irstea.fr

Specialty section:

This article was submitted to Biogeography and Macroecology,

a section of the journal Frontiers in Ecology and Evolution

Received: 28 September 2018 Accepted: 01 February 2019 Published: 07 March 2019

Citation:

Baltzinger C, Karimi S and Shukla U (2019) Plants on the Move: Hitch-Hiking With Ungulates Distributes Diaspores Across Landscapes. Front. Ecol. Evol. 7:38. doi: 10.3389/fevo.2019.00038
We here describe the multiple mechanisms by which ungulates distribute diaspores across landscapes. There are three primary and three secondary seed dispersal mechanisms by which ungulate dispersal agents contribute to the spread of plant diaspores, both with and without the intervention of other biotic and abiotic agents. These dispersal mechanisms may be combined in successive inter-dependent steps. Native, introduced and domestic ungulates co-occur in many ecosystems and frequently interact with numerous plant species, which facilitates long-distance dispersal of both native and exotic plants. However, ungulate taxonomic diversity conceals a much higher diversity in terms of the functional traits involved in ungulate-mediated dispersal (e.g., feeding regime, fur morphology). These traits may strongly affect emigration, transfer and immigration in the animal-mediated plant dispersal, and consequently; they may also impact overall seed dispersal effectiveness, both quantitatively and qualitatively. In this review, we compare internal mechanisms, where seeds must survive digestive treatments (regurgitation, endozoochory), with external mechanisms, where diaspores are carried on the outside of the vectors (epizoochory). We include both primary epizoochory (direct adhesion to fur essentially) and secondary epizoochory (diaspore-laden mud adhering to hooves or the body and, transfer through contact with a conspecific). We addressed the overlap/complementarity of ungulates for the plant species they disperse through a systematic literature review. When two ungulate species co-occur, there is always an overlap in the plant species dispersed by endozoochory or by fur-epizoochory. Further, when we consider the proportion of plant species dispersed both internally and externally by an ungulate, the overlap is higher for grazing than browsing ungulates. We identify two challenges for the field of dispersal ecology: the proportion of all diaspores produced that are carried over long distances by ungulates, and the relative importance of ungulates on the whole as the main dispersal agent for plants. Furthermore, the fact that numerous plants dispersed by fur-epizoochory do not feature any specific adaptations is intriguing. We discuss unsolved methodological challenges and stress research perspectives related to ungulate-mediated dispersal: for example, taking animal behavior and cognition into account and studying how ungulates contribute to the spread of invasive exotic plants and altitudinal plant dispersal.

Keywords: epizoochory, endozoochory, long distance dispersal (LDD), functional diversity index, plant-animal interactions 


\section{INTRODUCTION}

Contrasting with the defaunation process currently impacting large mammals in tropical forest ecosystems (Galetti and Dirzo, 2013), ungulate populations in temperate forests are rapidly increasing, sometimes locally reaching higher populations than their historic records. This phenomenon concerns overabundant native deer populations (Côté et al., 2004) and introduced species thriving in different parts of the world (e.g., Canada, Japan, Australia, New Zealand).

They are mostly large mammals, their body mass ranges from kilograms to hundreds of kilograms, that inhabit open, semi-open and closed habitats (Loison et al., 1999). These animals explore large home ranges and cover long daily distances across composite landscapes, along more or less sinuous paths (e.g., the gradient in path tortuosity from roe deer-Capreolus capreolus, to red deer-Cervus elaphus, to wild pig-Sus scrofa, in Pellerin et al., 2016). Since they are mainly herbivores, they process and transport plant materials when roaming their home ranges, and are thus involved in ecosystem engineering by chemical transport (Wilby et al., 2001) through nutrient fluxes and contribute to soil chemical content heterogeneity (e.g., by feeding in nutrient-rich areas and randomly releasing feces in forest-poor areas, Abbas et al., 2012; Murray et al., 2013). Albert et al. (2015a) demonstrated that temperate ungulates dispersed $44 \%$ of the regional pool of plants. Ungulate-mediated plant dispersal mainly occurs in the summer-fall seasons when most diaspores shed (Malo and Suárez, 1995). Dispersal also depends on ungulate feeding regime and other specific traits (Albert et al., 2015b).

Endozoochory, including frugivory, is the most widely studied ungulate-mediated plant dispersal mechanism (e.g., hoof- and fur-epizoochory concerns $<12 \%$ of the samples, see Table 3 in Albert et al., 2015a). However, Albert et al. (2015a) also stressed that, even though they are comparatively understudied, hoof- and fur-epizoochory were more selective processes than endozoochory and ungulates are involved in many different dispersal processes, both internal and external. Ungulate regurgitation, for instance, has been studied even less than hoof- and fur-epizoochory. This research gap seems logical since seed dispersal for fleshy-fruited plants occurs mainly in the tropics where birds, bats, primates and rodents are the main dispersal vectors (Jordano, 2000). Recently, however, more emphasis has been placed on other taxa, for instance reptiles (Sobral-Souza et al., 2017). Ungulates are important in plant dispersal for different reasons. First, they may play a role in longdistance plant dispersal (with maximal endozoochorous dispersal distances varying from $2.0 \mathrm{~km}$ for roe deer to $3.5 \mathrm{~km}$ for red deer, Pellerin et al., 2016). Second, they are present worldwide (except for Antarctica), either as native or introduced species and they have great taxonomic diversity (240 and 17 species within the Artiodactyla and Perissodactyla orders, respectively, Wilson and Reeder, 2005). Their communities are diverse (e.g., 5 species in remnant old-growth forests in Poland-Jaroszewicz et al., 2013; 10 species in Renosterveld, South Africa-Shiponeni and Milton, 2006; see Table 3), and they occur in a variety of ecosystems (e.g., forests, tree savannahs, grasslands). Finally, they have high functional diversity in plant-dispersal related traits (Albert et al., 2015b), e.g., various feeding regimes (Hofmann, 1989) and a wide range of body sizes (Clauss et al., 2007).

Mc Alpine et al. (2016) called for the integration of plantand animal- based approaches for biodiversity conservation actions and restoration efforts. Emphasis should be on key biotic interactions, for example how both plants and animals are involved in pollination and plant dispersal. Recent studies in various ecosystems suggest that many ungulates-native (e.g., white-tailed deer-Odocoileus virginianus, Connecticut, Williams and Ward, 2006), domestic (e.g., cattle-Bos taurus, California, Chuong et al., 2016) and introduced (e.g., Philippine deer-Rusa marianna and wild pig, Mariana Islands, Gawel et al., 2018) are involved in the spread of exotic plants, questioning their potential to help restore degraded habitat. Human-modified ecosystems and plant communities can also be affected by the presence of these large ungulates.

In this review, we aim to shed new light on the specific role of ungulates in long-distance plant dispersal, and to better understand how they have contributed to past plant distribution patterns, how they shape present plant communities and how they might help future plant communities cope with rapid and drastic human-induced changes (e.g., land use modifications, biological invasions, global warming, habitat loss and fragmentation, Mc Conkey et al., 2012).

We have specifically addressed the following four objectives. In the first part, we sum-up the primary and secondary dispersal mechanisms through which ungulates distribute diaspores across landscapes and describe how each of these processes influences the fate of the diaspores carried by the vectors. We highlight diplochorous sequences where ungulates are involved in at least one of the dispersal steps. In the second part, we propose to adapt the seminal conceptual framework of seed dispersal effectiveness for frugivory and endozoochory proposed by Schupp (1993) and revisited by Schupp et al. (2010) to the two other ungulatemediated primary processes: regurgitation and fur-epizoochory. In the third part, we discuss the functional diversity of ungulates, how it might affect the fate of the seeds dispersed, and how this should be used to build further research. In the fourth part, we performed a systematic literature review to assess the overlap and complementarity of sympatric ungulates in plant dispersal first and then of different ungulate-mediated plant dispersal mechanisms. Finally, we discuss unsolved methodological challenges, potential ungulate-mediated habitat restoration options and suggest research perspectives.

\section{DIVERSITY OF UNGULATE-MEDIATED DISPERSAL MECHANISMS}

No review to date has systematically addressed all the dispersal mechanisms through which ungulates convey diaspores across the landscapes. These mechanisms comprise both internal and external dispersal, primary and secondary dispersal events (i.e., diplochory, Vander Wall and Longland, 2004). They involve either biotic vectors alone (ungulates, ungulates and coprophagous beetles-D'hondt et al., 2008), or more complex 
systems involving primates or birds, ungulates and coprophagous beetles (Newton, 1989) or both abiotic vectors (wind, water, gravity) and ungulates. These different mechanisms move diaspores from the parent plant to different releasing locations. Some primates or birds feeding on fruits in the tree canopy can make them fall to the ground where they become accessible to forest-dwelling ungulates. These interactions were reviewed by Newton (1989) and have more recently been assessed for the langur-chital association in India (Ramesh et al., 2012).

Internal mechanisms (left side of Figure 1) concern consumed diaspores, which must withstand digestion (mechanical, thermal and chemical treatments). They include two specific processes: regurgitation, or partial endozoochory (where diaspores are ingested and regurgitated, Prasad et al., 2006), and full endozoochory (where diaspores are ingested and defecated). External mechanisms (right shaded side of Figure 1), where diaspores are carried on the outside of the vectors on various body parts, include primary fur-epizoochory (direct adhesion to fur essentially) and secondary epizoochorous processes: transfer through contact with a conspecific (Liehrmann et al., 2018) and diaspore-laden mud adhering to hooves (Schulze et al., 2014) or the body (Heinken and Raudnitschka, 2002). We have used a model ungulate to depict primary and secondary dispersal mechanisms of diaspores from a parent plant present in its home range (Figure 1).

\section{Regurgitation or Partial Endozoochory}

First, let us look at one of the most understudied primary internal processes, regurgitation or partial endozoochory (described by scenario In1a in Figure 1). Here, fruit is ingested, then the endocarp is regurgitated after a lapse of time in the rumen. Regurgitation has been documented all around the world: e.g., in India for the different fruits consumed by the chital (Axis axis, Prasad et al., 2006), in Mexico for the white-tailed deer (Mandujano et al., 1994), in western Africa for the duikers (Cephalophus sp., Feer, 1995), in southern Morocco for goats (Capra aegagrus hircus, Delibes et al., 2017), and more recently, in Spain for red deer (Castañeda et al., 2017). Some fleshy-fruited plants known to be consumed by European roe deer (Cornelis et al., 1999; Cransac et al., 2001) for example, dogwood (Cornus sanguinea) and ivy (Hedera helix) share similar characteristics (fruit, endocarp and seed size) with the plants mentioned in these studies. Dogwood and ivy do not germinate from roe deer dung samples (Heinken et al., 2001; Picard et al., 2016); we therefore suppose that the endocarps are regurgitated and not defecated. Clean regurgitated endocarps were found at specific and predictable resting/ruminating sites (i.e., directed dispersal, Wenny, 2001) whereas defecated seeds were more or less randomly deposited within the home range.

\section{Endozoochory and Secondary Dispersal by Dung Beetles}

Now let us look at the most studied primary internal process: endozoochory (Picard et al., 2016, described by scenario In1b in Figure 1). Here diaspores are consumed, undergo complete gut passage and are defecated. Releasing sites are much less predictable than for regurgitation as ungulates can defecate away from their resting/ruminating site, while walking or feeding. Feces and their diaspore content can then be mobilized by other biotic vectors in a secondary step as depicted with coprophagous beetles (scenario Bi2, Figure 1). Depending on their functional group (Milotić et al., 2018, 2019), dung beetles move diaspores horizontally (small and large rollers), bury them more or less deeply (small and large tunnellers and rollers, D'hondt et al., 2008) or leave them roughly in the same place (dwellers). This case is known as diplochory, or secondary dispersal.

\section{Fur-Epizoochory Including Transfer-Epizoochory}

The right side of Figure 1 represents external processes, which have been much less studied than endozoochory (Albert et al., 2015a). One primary external process is fur-epizoochory (described by scenario Ex1, Figure 1). Here diaspores become attached to the fur of passing ungulates. Diaspores carried in the fur of ungulates generally present a high turn-over-most of them will fall off during the first few hours (Bullock et al., 2011) - though attachment time does depend on the characteristics of the fur (e.g., hair curliness, hair length, Liehrmann et al., 2018). Diaspores can drop accidentally or the animals can detach them during specific grooming sessions with teeth, by scratching or by rubbing against tree trunks (Heinken et al., 2006). Allo-grooming events or games between conspecifics in social ungulates can also lead to secondary external dispersal (described by scenario Ex2a, Figure 1). Liehrmann et al. (2018) have recently documented this mechanism, called transferepizoochory for dwarf goats, Poitou donkeys and red deer hinds. Diaspore transfers might occur more frequently during the reproduction period and while rearing young. We also suppose that transferred diaspores move from the home range of the first vector to the neighboring home range of its conspecific (Figure 1).

\section{Hoof-Epizoochory}

When diaspores are not dispersed by ungulates and other biotic or abiotic vectors, they simply fall to the ground when the parent plant withers, this is called barochory (described by scenario Ab1, Figure 1). These diaspores therefore have a maximal distance equivalent to the diaspore releasing height. All the diaspores released on the ground within the ungulate's home range, whatever the dispersal process, constitute the soil surface pool (Box 1). These diaspores may either germinate and take root, enter the soil seed bank or be dispersed again by ungulates through hoof-epizoochory (described by scenario Ex2b, Figure 1), as often occurs on loose soils when diasporeladen mud sticks to the hooves (roe deer, red deer and wild pig in Picard and Baltzinger, 2012; European bison-Bison bonasus in Schulze et al., 2014) or to other body parts. Secondary epizoochory may also happen when ungulates like wild pig wallow for thermal comfort or to get rid of ectoparasites (Heinken and Raudnitschka, 2002). These diaspores can drop off further along trails (e.g., white-tailed deer in Lefcort and Pettoello, 2012; and horse, Equus caballus in Wells and Lauenroth, 2007) where germinating conditions may be more 


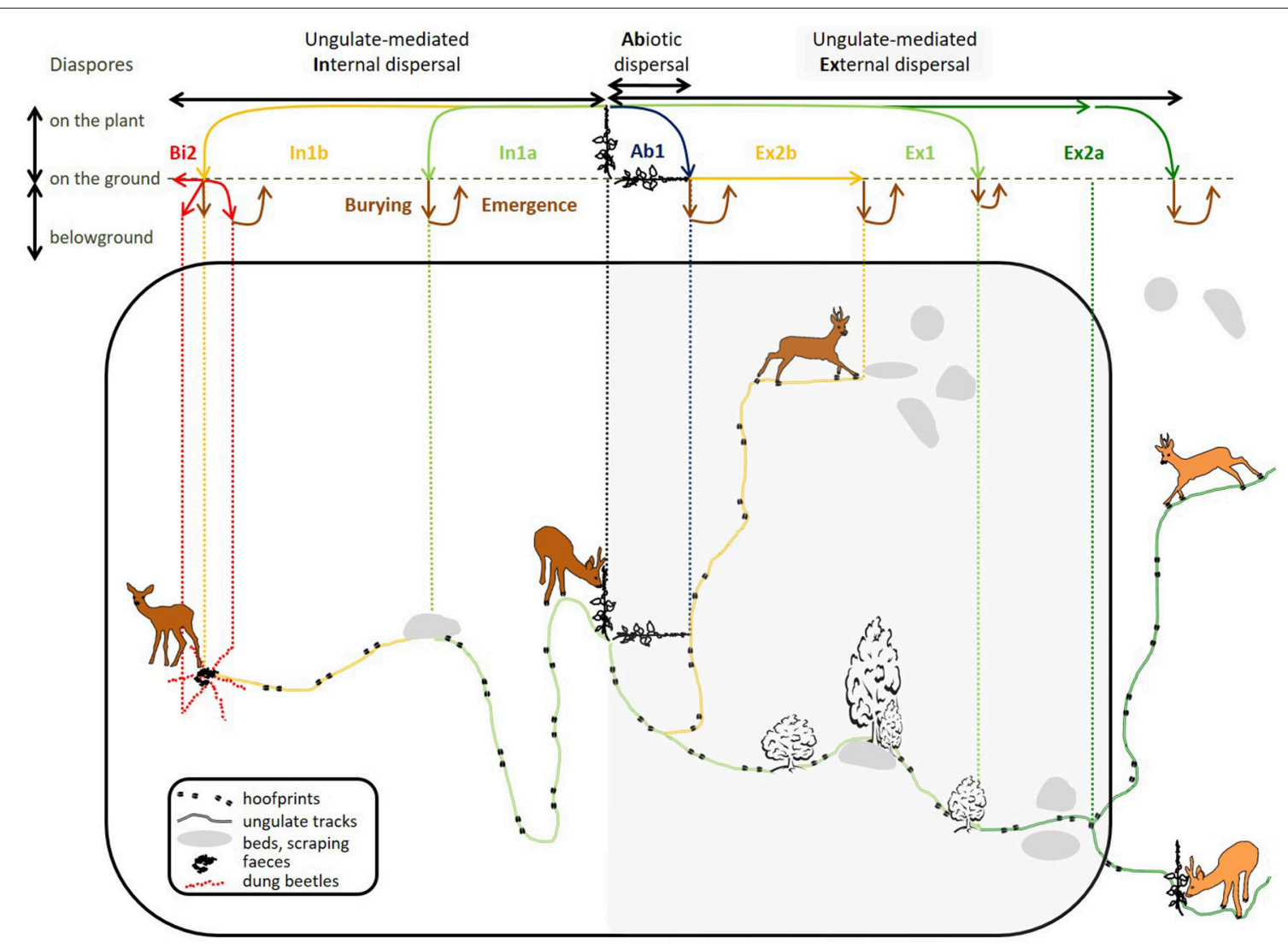

FIGURE 1 | General spatial representation of primary internal ungulate-mediated plant dispersal mechanisms (indicated by 1: In1a regurgitation, In1 b endozoochory) and primary (Ex1 fur-epizoochory) and secondary external ungulate-mediated plant dispersal mechanisms (indicated by 2: Ex2a transfer-epizoochory, Ex2b hoof-epizoochory) and the associated horizontal and vertical trajectories of the carried diaspores. To the left side of the parent plant, the diagram describes internal mechanisms; the shaded part to the right represents external mechanisms. Abiotic dispersal by gravity (Ab1 barochory) can be considered as a first step of dispersal. And secondary dispersal by other biotic vectors like coprophagous beetles (Bi2) is considered as a second step following endozoochory (In-1b). The top part of the diagram shows the fate of a diaspore for each dispersal mechanism from the parent plant to its final destination (moving from the diaspore regional pool to the transferred pool, the soil surface pool and finally, the soil seed bank, Box 1). The large black rectangular shape delimits the home range of the vector.

favorable, for example in microhabitats like hoof prints of ungulates (Figure 1) where rainwater can stand longer. Diaspores can also drop off nearby rubbing trees (Welander, 2000).

\section{Spatial Trajectory of Conveyed Diaspores}

The top part of Figure 1 shows the fate, spatial trajectory and associated successive movements (from release by the parent plant to deposition on the ground) of the conveyed diaspores for each dispersal mechanism considered (the color code corresponds to the associated internal or external mechanism). Some of the diaspores will contribute to the build-up of the soil seed bank (Jaroszewicz, 2013) through gradual burying (Burying, Figure 1) or thanks to the tunneling activities of paracoprid and telecoprid dung-beetles and can further reemerge (Emergence, Figure 1) on the soil surface through physical changes in the soil, with or without mediation by ungulates (Jones et al., 1994) to find propitious germination conditions (e.g., light and humidity).

\section{SEED DISPERSAL EFFECTIVENESS REVISITED FOR UNGULATE-MEDIATED PROCESSES INCLUDING REGURGITATION AND FUR-EPIZOOCHORY}

Schupp (1993) defined a conceptual framework to study seed dispersal effectiveness (SDE), defined as the result of a quantitative component, the emigration phase, and a qualitative component, the transfer and immigration phases (Table 1). The plant dispersal process is therefore composed of three distinct phases, namely emigration, transfer, and immigration (Table 1). The emigration phase for ungulate-mediated dispersal relies on the spatial and temporal availability of diaspores in the vegetation physically accessible within the home range of a given dispersal agent. This diaspore load depends on the interaction between the traits of the plant and of its diaspores and the traits of the dispersal agent (Albert et al., 2015b). The transfer phase determines the trajectory covered by the diaspores transported by the dispersal agent during gut retention and 
Box 1 | Spatial and temporal diaspore availability within ungulate home ranges and populations.

The regional plant pool corresponds to all the plants in their adult reproductive stage accessible to the ungulate, within its home range or within the geographic area occupied by the population of ungulates. The local plant pool corresponds to the plants members of the plant community at the local scale.

At the diaspore stage (e.g., seed, fruit) and within an ungulate's home range, four pools of diaspores differ in their spatial and temporal availability: the regional diaspore pool, the transferred diaspore pool, the soil surface diaspore pool, and the soil seed bank.

- The regional diaspore pool defines all the diaspores available on the parent plants at diaspore releasing height during the seed shedding period. Some plants maintain a dead erect stem and therefore lengthen temporal availability for potential dispersal agents.

- The transferred diaspore pool defines diaspores when they have left the mother plant via biotic or abiotic dispersal. The duration and associated distance of the ungulate-mediated transfer phase depend on internal or external retention time (Figure 2).

- The soil surface diaspore pool combines diaspores released on the ground by biotic or abiotic vectors with diaspores falling on the ground when the plant withers. In that case, maximal dispersal distance equals diaspore releasing height. Released diaspores can germinate, be moved by dung beetles or between the hooves of ungulates during secondary dispersal, or build-up the soil seed bank.

- The soil seed bank includes diaspores with varying longevity, from transient ( $<1$ year), short-term ( $<5$ years) to longer term (over 5 years, as for soft rush, Juncus effusus). These diaspores can encounter favorable germination conditions following soil disturbance and/or improved light conditions at different time scales.

regurgitation time or the time elapsed between the attachment of the diaspore to the dispersal agent and its detachment. The immigration phase concerns the germination of the released diaspores, their establishment as seedlings, their growth to adult plants able to reproduce. Thus ungulate-mediated seed dispersal is potentially important for plant demography from one generation to the next (Wang and Smith, 2002; Vellend et al., 2006) and plays a role in metapopulation dynamics (e.g., Figure 6 in Jabot et al., 2008, and the link between migration and the proportion of mammal-dispersed trees). In an updated version of this conceptual framework, Schupp et al. (2010) suggested that their framework should not be restricted to the sole study of frugivory and endozoochory, but that it could be adapted to other dispersal processes like fur-epizoochory. In Table 1, we follow this suggestion by comparing the three primary ungulatemediated dispersal processes: endozoochory and regurgitation (internal) and fur-epizoochory (external). We will sequentially treat the different components and sub-components involved in SDE and highlight the ungulate characteristics that affect each dispersal phase.

The quantitative component (emigration phase) corresponds to the product of the number of visits to the plant and the number of diaspores loaded per visit (Table 1).

\section{Number of Visits}

Whatever the dispersal process considered, the number of visits to the parent plant will depend on three parameters: the local ungulate abundance, a degree of selectivity and the frequency and length of contacts with the parent plant. For internal dispersal processes (endozoochory and regurgitation), feeding selectivity will determine where, when and which plant will be consumed (Boulanger et al., 2009) and will depend on the feeding regime of the ungulate considered. For instance, Intermediate Mixed Feeders like the red deer (Latham et al., 1999; Gebert and Verheyden-Tixier, 2001) are less selective and consume a higher diversity of plants than sympatric Concentrate Selectors like roe deer (Cornelis et al., 1999; Cransac et al., 2001). The frequency and the length of the feeding bouts will also determine the occurrence of contacts with the selected feeding items. The number of active bouts (including feeding bouts) varies across the year and is generally higher during summer (e.g., 12 for red deer-Pépin et al., 2006; 16 for moose, Alces alces and 26 for roe deer in Cederlund, 1989). By comparison with external processes (fur-epizoochory), daily home range fidelity (Richard et al., 2014), how regularly ungulates use the same paths (Wells and Lauenroth, 2007; Torn et al., 2010; Lefcort and Pettoello, 2012) or how frequently they use specific parts (e.g., core areas in Le Corre et al., 2009) of their home range should determine the number of visits. The frequency of the active bouts and their length during each visit will lead to the passive attachment of some diaspores to different body parts of the ungulate (Fischer et al., 1996), more specifically to the head and/or the breast of the animal while feeding on specific plants ("foliage is the fruit" hypothesis extended to fur-epizoochoryJanzen, 1984; Couvreur et al., 2005).

\section{Number of Diaspores Loaded Per Visit}

The number of diaspores consumed during each visit will depend on the feeding regime. More diaspores are consumed by generalist herbivores like Grass and Roughage Eaters (e.g., European bison, cattle) or Intermediate Mixed Feeders (e.g., red deer, chamois-Rupicapra rupicapra) than by more selective herbivores like Concentrate Selectors (e.g., roe deer, moose in Hofmann, 1989). It will also depend on the body mass, as heavier species and heavier individuals will eat more plant material than lighter ones to meet energy requirements (e.g., the difference between two concentrate selectors: roe deer, $<30 \mathrm{~kg}$ vs. moose, $>300 \mathrm{~kg}$, Loison et al., 1999). Finally, diaspore availability on the plant and its accessibility to the ungulates also have an influence (Box 1). Albert et al. (2015b) showed that Concentrate Selectors consumed diaspores at a specific diaspore releasing height. Some of the diaspores detached from the parent plant might be lost before ingestion, especially when the fruits and diaspores are not the main focus of the feeding bouts and are accidentally consumed (Janzen, 1984). For fur-epizoochory, the number of diaspores loaded during each visit will depend on the number of diaspores attached per contact, resulting from the interaction between diaspore releasing height and ungulate body height (Fischer et al., 1996; Albert et al., 2015b). The number of diaspores attached to the ungulate body also depends on fur characteristics like hair length and curliness (Albert et al., 2015b) 
TABLE 1 | Components of ungulate-mediated seed dispersal effectiveness comparing three primary processes: endozoochory, regurgitation and fur-epizoochory [modified from Table 1 in (Schupp, 1993), and Figure 2 in Schupp et al., 2010].

\begin{tabular}{|c|c|c|c|c|c|}
\hline Plant dispersal & Component & Sub-component & Endozoochory & Regurgitation & Fur-epizoochory \\
\hline \multirow[t]{2}{*}{ Emigration phase } & $\begin{array}{l}\text { Quantitative } \\
\text { How many diaspores } \\
\text { are loaded by the } \\
\text { vector? }\end{array}$ & Number of visits & \multicolumn{2}{|c|}{$\begin{array}{l}\text { - Local ungulate abundance } \\
\text { - Selective feeding (feeding regime) }\end{array}$} & $\begin{array}{l}\text { - Local ungulate abundance } \\
\text { - Within home range fidelity } \\
\text { (used trails, core areas) } \\
\text { - Frequency and length of } \\
\text { active, including feeding, } \\
\text { bouts }\end{array}$ \\
\hline & & $\begin{array}{l}\text { Number of diaspores } \\
\text { loaded per visit }\end{array}$ & \multicolumn{2}{|c|}{$\begin{array}{l}\text { - Number of diaspores consumed per visit } \\
\text { - Loss before and during ingestion } \\
\text { - Physical accessibility } \\
\text { - Body mass }\end{array}$} & $\begin{array}{l}\text { - Number of diaspores hung } \\
\text { per contact } \\
\text { - Loss by grooming } \\
\text { - Height of contact } \\
\text { - Body surface, body part } \\
\text { and fur characteristics }\end{array}$ \\
\hline \multirow[t]{2}{*}{ Transfer phase } & \multirow[t]{2}{*}{$\begin{array}{l}\text { Qualitative } \\
\text { What is the chance for } \\
\text { a loaded diaspore to } \\
\text { become an adult plant? }\end{array}$} & $\begin{array}{l}\text { Treatment quality by } \\
\text { the vector }\end{array}$ & $\begin{array}{l}\text { - Mechanical (mastication), } \\
\text { thermal and chemical } \\
\text { (digestive strategy) } \\
\text { - Gut passage time } \\
\text { (Figure 2) }\end{array}$ & $\begin{array}{l}\text { - Mechanical } \\
\text { (mastication), thermal } \\
\text { and chemical } \\
\text { (rumination) } \\
\text { - Regurgitation time }\end{array}$ & $\begin{array}{l}\text { - Mechanical (rubbing), } \\
\text { thermal (body temperature } \\
\text { buffer) and climatic } \\
\text { (humidity) } \\
\text { - External retention time } \\
\text { (Figure 2) }\end{array}$ \\
\hline & & $\begin{array}{l}\text { Deposit quality of the } \\
\text { released diaspores }\end{array}$ & $\begin{array}{l}\text { - Random or directed } \\
\text { defecation } \\
\text { - Fecal matrix } \\
\text { - Diverse and numerous } \\
\text { diaspores }\end{array}$ & $\begin{array}{l}\text { - Regurgitation at } \\
\text { ruminating/resting } \\
\text { site } \\
\text { - No matrix } \\
\text { - Assumed few } \\
\text { diaspores at a time }\end{array}$ & $\begin{array}{l}\text { - Random or directed to } \\
\text { rubbing structures (trees, } \\
\text { rocks or the ground) } \\
\text { - No matrix } \\
\text { - Weakly diverse and } \\
\text { isolated diaspores }\end{array}$ \\
\hline Immigration phase & & $\begin{array}{l}\text { Quality of the } \\
\text { deposition site for } \\
\text { germination and growth }\end{array}$ & $\begin{array}{l}\text { - Environmental filter } \\
\text { (abiotic conditions) } \\
\text { - Strong biotic interactions } \\
\text { with predators, } \\
\text { decomposers, herbivores } \\
\text { or among plants }\end{array}$ & \multicolumn{2}{|c|}{$\begin{array}{l}\text { - Weak biotic interactions with predators, } \\
\text { herbivores or among plants }\end{array}$} \\
\hline
\end{tabular}

and on which body surface area is exposed (Bohême, 2012). Wild pig dispersed more diaspores of more plants than did red deer, and red deer more than did roe deer (see Figure 2 in Picard and Baltzinger, 2012). Bohême (2012) assessed the body surface exposed per individual for wild pig, red deer and roe deer and no longer found any significant difference in seed load per surface unit between red and roe deer. Liehrmann et al. (2018) confirmed the interspecific effects of fur characteristics (by comparing red deer, dwarf goat and Poitou donkey, Equus asinus) and extended that pattern to different body parts (head, flanks or rump) of a given individual. They also showed that some diaspores may be lost during auto-grooming events.

The qualitative component (transfer and immigration phases) combines the quality of the treatment exerted by the vector, the deposit quality of the released diaspores and finally the quality of the deposition site, i.e., both abiotic conditions and biotic interactions encountered at the release site (Table 1).

\section{Treatment Quality by the Vector}

Diaspores consumed by an ungulate undergo different treatments of variable duration: physical (mastication and rumination), and thermal and chemical (digestive process). Mastication, i.e., the chewing process, may lead to the destruction of the diaspores consumed; especially concerning large seeds (e.g., acorns). Indeed, most of the studies on ungulate endozoochory highlight preferential dispersal of small-sized (Janzen, 1984; Heinken et al., 2002; Pakeman et al., 2002; Picard et al., 2016) and rounded seeds (Mouissie et al., 2005a), which germinate in higher proportions in ungulate dung, though Bruun and Poschlod (2006) showed that this pattern might be linked to the greater overall availability of small seeds (i.e., reproductive trade-off). The digestive process itself adds thermal and chemical treatments in the gut (Milotić and Hoffmann, 2016b), which differentially affect the seed coat, its permeability and subsequent ability to germinate once released in the fecal matrix. Picard et al. (2015) showed, for instance that bramble (Rubus fruticosus) seeds germinated when consumed by wild pig whereas unconsumed control seeds and those consumed by ruminant deer species did not. Gut passage time is a function of ungulate body mass (Illius and Gordon, 1992) for both ruminants and non-ruminants: the heavier the animals the longer the transit (Clauss et al., 2007; and e.g., the shift between the roe deer and wild pig in Figure 2, Picard et al., 2015). Digestive systems opposing ruminants to non-ruminants will also have differing effects on the fate of the seeds. For ruminants, larger seeds will be processed longer and smaller ones will pass the gut more rapidly (Picard et al., 2015). Above a given size, endocarps from fleshy fruits will be regurgitated (Sridhara et al., 2016). Empirical experimental 


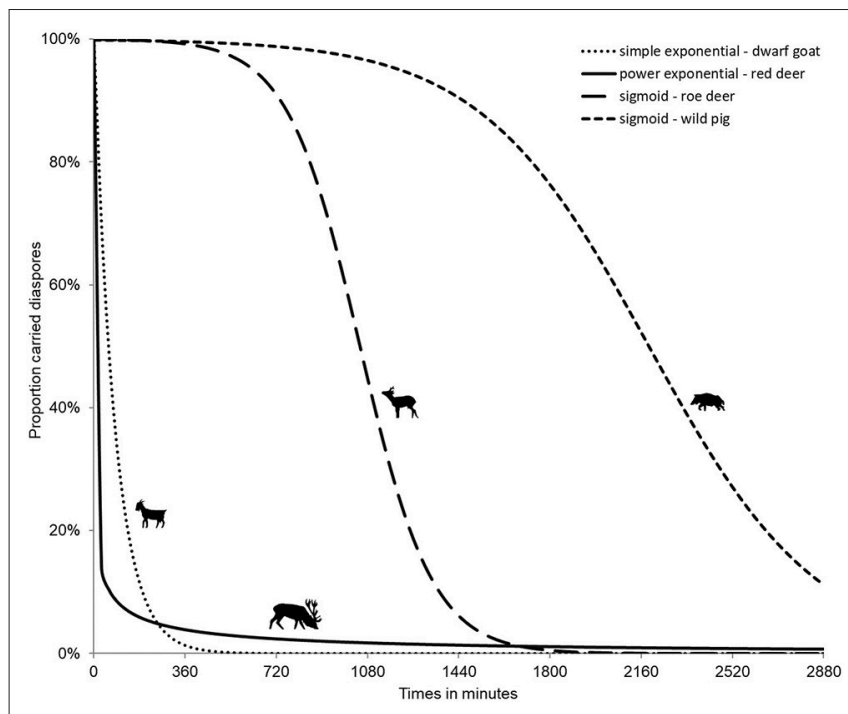

FIGURE 2 | Internal (endozoochory, right curves for roe deer, Capreolus capreolus and wild pig, Sus scrofa) and external (fur-epizoochory, left curves for dwarf goat, Capra aegagrus hircus and red deer, Cervus elaphus) diaspore retention time (adapted from Picard et al., 2015; Liehrmann et al., 2018).

data on gut passage time vary from 1 to 3 days for ungulates (e.g., Table 2 in Pakeman, 2001) for temperate forest ungulates ranging in body mass between $<30 \mathrm{~kg}$ (roe deer) and more than $300 \mathrm{~kg}$ (moose, Loison et al., 1999), though Illius and Gordon's equations have been questioned (Clauss et al., 2007). Internal retention time requires a minimal time for the first diaspores to be released, and non-ruminant species release different-sized diaspores simultaneously (Picard et al., 2015). Data on regurgitation times are scarce: in India for chital, they range from 7 to $27 \mathrm{~h}$ (Prasad et al., 2006) and for red deer in Spain from 1 to 4 days after ingestion (Castañeda et al., 2017).

The treatment effect for externally attached diaspores is much weaker. This effect could be linked to rubbing (against trees or through grooming) or to weather (body vs. air temperature and humidity-effect of precipitation). Whereas in internal processes, all diaspores are released after a specific gut passage time, in external processes like fur-epizoochory, most of the diaspores drop off very quickly, though but a few can be retained much longer (Figure 2, for red deer), thus contributing to very longdistance dispersal (Bullock et al., 2011; Liehrmann et al., 2018).

\section{Deposit Quality of the Released Diaspores}

As ungulates defecate either after leaving resting or ruminating sites, during walking, or feeding events, we can consider defecation sites to be randomly distributed in comparison to regurgitation sites, where endocarps are released only at ruminating sites (Prasad et al., 2006). However, Picard et al. (2016) suggest that internally-dispersed plants are typically selected in open feeding habitats and are then released when ungulates rest under forest cover (Abbas et al., 2012); this could be considered a non-random directional movement. Diaspores can detach accidentally and randomly from the fur, however it could also be considered as a non-random process of dispersal as evidenced by soil seed bank of diaspores near rubbing trees, where more viable diaspores are found than nearby non-rubbed trees (Welander, 2000; Heinken et al., 2006). The deposit quality of the released diaspores is linked to the presence of a fecal matrix. In experiments done with 15 grassland plants, Milotić and Hoffmann (2016c) showed that sowing seeds in ungulate dung reduced germination rate and lengthened germination time; this pattern was even stronger for cattle compared to horse dung. These findings highlight the significance of dung material characteristics (ruminant vs. non-ruminant) in deposit quality. The diversity of the feeding regime will determine the diversity of the seeds present in the dung (higher for Intermediate Mixed Feeder than for Concentrate Selector, e.g., Picard et al., 2016) and the body mass will determine the abundance of seeds, as heavier ungulates or individuals will ingest more plant material (red deer vs. roe deer, Picard et al., 2016). We assume that regurgitated endocarps might be less diverse as they generally concern one specific nutrientrich resource at a time (Prasad et al., 2006). As externally conveyed diaspores are not released in a fecal matrix, their chances to be released as isolated and undetectable diaspores in the field are high (e.g., through experimental assessment in Liehrmann et al., 2018).

\section{Quality of the Deposition Site for Germination and Growth}

The quality of the deposition site will, of course, depend on the local abiotic conditions (i.e., environmental filter, Kraft et al., 2015) including light, temperature and humidity. Ungulates leave hoofprints while walking on loose soils, and they also create specific microhabitats while scraping (e.g., roe deer in Johansson, 2000) or digging (e.g., wild pig in Welander, 2000) the ground. Acting as ecosystem engineers (Jones et al., 1994), they modulate the resources available to other taxa, including diaspores. The quality of the deposition site will also depend on biotic factors. The presence of the fecal matrix, which differentiates full endozoochory from both regurgitation and fur-epizoochory, will favor biotic interactions with different functional and taxonomic groups. Decomposers (e.g., soil macroinvertebrates, different types of dung beetles, Milotić et al., 2018, 2019) will move diaspores toward specific microhabitats. D'hondt et al. (2008) showed that dung beetles had a negative effect on short-term seedling establishment, probably due to the deep burial of diaspores by large tunnellers. Fungi frequently develop on feces and may affect the tegument of the dispersed seeds. Small rodents, attracted by the clumped seeds in the feces, may also predate on the seeds dispersed. Other plants may benefit from the nutrients released and compete for resources with establishing seedlings. Milotić and Hoffmann (2016a) showed that the effect of the fecal matrix was beneficial for post-germination stages of the plant development. Large herbivores that feed selectively on nitrophilous plants (Janzen, 1984; Albert et al., 2015a) may be attracted by nutrient-rich vegetation patches, and also interact at the deposition site with establishing seedlings. 
TABLE 2 | Effects of ungulate functional diversity gradients on the different phases of internal (endo: endozoochory and regurgitation) and external (epi: fur-epizoochory) plant dispersal (CS: Concentrate Selector, IMF: Intermediate Mixed Feeder, GRE: Grass and Roughage Eater and OM: Omnivore).

\begin{tabular}{|c|c|c|c|c|}
\hline Socio-spatial scale & Ungulate characteristics & Emigration & Transfer & Immigration \\
\hline \multirow{7}{*}{$\begin{array}{l}\text { Individual level (physiology } \\
\text { and morphology) }\end{array}$} & Body mass & endo $a, b$ & endo ${ }^{C}$ & \\
\hline & Feeding regime (CS, IMF, GRE, and OM) & endo $\mathrm{b} / \mathrm{epi}^{\mathrm{d}}$ & & \\
\hline & Digestive strategy (ruminant or not) & & endo ${ }^{c, e}$ & \\
\hline & Body size (shoulder height) & endo ${ }^{f} /$ epif,g & & \\
\hline & Body surface area & epi ${ }^{\text {h }}$ & epi ${ }^{\text {h }}$ & \\
\hline & $\begin{array}{l}\text { Fur characteristics (hair length and curliness, fur } \\
\text { thickness) }\end{array}$ & epi ${ }^{i, j}$ & epi ${ }^{i, j}$ & \\
\hline & Auto-grooming (wallowing, rubbing against structures) & epi & epi $\mathrm{j}^{\mathrm{j}, \mathrm{k}, \mathrm{l}}$ & epik,l \\
\hline \multirow[t]{2}{*}{ Population level } & Sociality/hierarchy (from pairs to herds) & epim/endom & epi & \\
\hline & Allo-grooming & epi & epij & \\
\hline \multirow[t]{2}{*}{ Landscape level } & Habitat use (home range fidelity, activity rhythm) & endo $^{\mathrm{n}, \mathrm{o}, \mathrm{p}} / \mathrm{epi} \mathrm{i}^{\mathrm{n}, \mathrm{o}, \mathrm{p}}$ & $e{ }^{n} o^{n, o, p} / e^{n}{ }^{n, o, p}$ & endo $^{n, o, p} /$ epi $^{n, o, p}$ \\
\hline & Movement (home range size, daily distance, tortuosity) & & endoq,r/epiq,r & \\
\hline
\end{tabular}

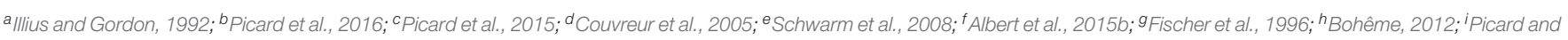

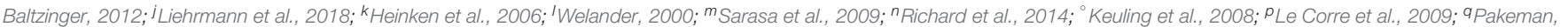
2001; 'r Pellerin et al., 2016.

Upper letters refer to citations listed below the table.

\section{THE FUNCTIONAL DIVERSITY OF UNGULATES AND ASSOCIATED EFFECTS ON THE FATE OF DIASPORES}

The ungulates are numerous and taxonomically and functionally diverse (Groves and Grubb, 2011). This diversity may intervene at different steps in ungulate-mediated diaspore dispersal processes, from the scale of the individual vector to groups of individuals, populations and communities (Table 2). At the scale of the individual, mostly physiological and morphological traits will be concerned, and are depicted in the two following sub-sections. The third sub-section reports to higher scales of organization (i.e, from pairs to groups of individuals).

\section{Body Mass, Feeding Regime and Digestive Strategy}

Concerning endozoochory, large body mass increases the amount of diaspores consumed (Picard et al., 2016), and once consumed, body mass will affect gut retention time (Picard et al., 2015 but see Steuer et al., 2011 for a comprehensive review). Furthermore, gut retention time varies with diaspore size (Clauss et al., 2009; Picard et al., 2015). Digestive strategy will also affect endozoochory, with ruminants sorting food items according to their size (Schwarm et al., 2008). Picard et al. (2015) showed that smaller rounded diaspores were retained for shorter times in the gut of red and roe deer than were larger diaspores, whereas in wild pig all types of diaspores were generally released at the same time (see also differences between banteng, Bos javanicus and pygmy hippopotamus, Hexaprotodon liberiensis in Schwarm et al., 2008). Feeding regime will determine the growth form, diversity and amount of the plants consumed (European bison, a Grass and Roughage Eater, Kowalczyk et al., 2011; red deer, an Intermediate Mixed Feeder, Gebert and Verheyden-Tixier, 2001; roe deer, a Concentrate Selectors, Cornelis et al., 1999 and wild pig, an Omnivore, Schley and Roper, 2003), but also which part of the plant is consumed, with browsers being much more selective than grazers. Feeding regime will affect the emigration phase for both endo- and fur-epizoochory, because by feeding and spending time in open areas, herbivores will enhance chances for diaspores to attach to different parts of their body (e.g., head, belly, flanks).

\section{Body Size, Body Surface, Fur Characteristics and Grooming}

Body size, with respect to plant-animal interactions, relates to the height at which vegetation is encountered in the area explored by the ungulates. This affects both endo- and fur-epizoochory as it determines which plants are accessible, or reachable, for feeding (Fischer et al., 1996; Albert et al., 2015b). Albert et al. (2015b) showed that body size approximated by shoulder height interacted with plant diaspore releasing height for both endozoochory (i.e., which vegetation layers are consumed) and fur-epizoochory (i.e., which vegetation can touch the animal's body). Eventhough, ungulates may stand on their hind legs or take advantage of snow cover to access vegetation above their head height, shoulder height remain a good predictor that can be used for comparative approaches. Body surface area is another important characteristic with regard to external dispersal. Bohême (2012) revealed that the abundance of diaspores on different individuals with similar fur characteristics (red deer and roe deer) was directly related to the total surface area made accessible to the plants to attach. Liehrmann et al. (2018) further showed that hair length and curliness were also factors of diaspore attachment and detachment. Ungulates such as the Poitou donkey (undercoat and long hairs) or the wild pig stock the diaspores in their fur, while others like the dwarf goat (short and wavy hairs) or the red and roe deer showed a rapid turnover of diaspores. Fur thickness can affect diaspore 
attachment and detachment and thus directly determine the time the diaspores stay attached to the different parts of the animal's body. Finally, single individuals will groom themselves with their teeth or legs (Liehrmann et al., 2018), rub against trees or wallow to get rid of parasites (Welander, 2000; Heinken et al., 2006). These grooming events will affect the loss, the gain and also the transfer phase of different diaspores.

\section{Sociality, Habitat Use and Movement Patterns}

At the population scale, or at least for individuals living in pairs, interactions among individuals (e.g., playing games, motheryoung relationships, resting in groups, allo-grooming) can lead to both diaspore detachments and transfers from one individual to another (Liehrmann et al., 2018). These interactions will mainly affect external seed dispersal. Sarasa et al. (2009) showed that the access by Iberian ibex to feeding stations was dependent on the sex and age of the individuals, which conditioned the access to the vegetation but also the infestation by pseudoectoparasites, and potentially the attachment of diaspores adapted to furepizoochory. At larger scales, the way ungulates use the different habitats that compose their home range will affect the fate of seed dispersal (e.g., Keuling et al., 2008 for the wild pig; Le Corre et al., 2009 for the roe deer). Picard et al. (2016) suggested that feeding habitat preferences filtered out some of the potential diaspores which could be conveyed by ungulates. Directed dispersal might occur if animals regularly return to the same sites and use the same trails between feeding and resting/ruminating sites. Home range fidelity at different temporal scales (e.g., day, season, year, Richard et al., 2014) also means that ungulates might move diaspores to very predictable places associated to routine movements (Riotte-Lambert et al., 2017). The alternation of active and passive bouts of interaction with vegetation also determines when diaspores are attached and when they can be released. The extent (see definition in Pakeman, 2001) of the home range, which is closely related to animal body mass and energy requirements, constrains daily movements and determines how animals explore the space available. For instance, roe deer describe more tortuous trajectories than do red deer or even wild pig (Pellerin et al., 2016), leading to shorter dispersal distances for a given walked distance.

\section{OVERLAP AND COMPLEMENTARITY OF UNGULATE-MEDIATED DISPERSAL}

In plant dispersal networks, diaspores produced by the parent plant can be dispersed through endozoochory by different co-occurring vectors. These networks have been established principally for frugivory and endozoochory (Dugger et al., 2018; Miguel et al., 2018). Fedriani and Delibes (2009) studied the role of different mammals (e.g., wild pig; red deer; badger, Meles meles and red fox, Vulpes vulpes) dispersing the Iberian pear (Pyrus bourgaeana). Jaroszewicz et al. (2013) showed that numerous plant species were dispersed by a guild of dispersal agents (Table 3). On the other hand, situations also occur where one specific ungulate vector disperses the same plant through different mechanisms, i.e., endozoochory, fur- and hoofepizoochory. Birch (Betula pendula) was dispersed between the hooves and on the fur of wild pig, red deer and roe deer (Picard and Baltzinger, 2012). Both the characteristics of the dispersal vector and the considered mechanism will ultimately affect seed dispersal effectiveness (Table 1) and may generate complex and unpredictable dispersal kernels.

In this section, we look at plant species that can potentially germinate after long-distance ungulate-mediated dispersal; however, without considering how the transfer phase occurred. We emphasize the overlap and complementarity resulting from co-occurring ungulates, which disperse plants through either endozoochory or fur-epizoochory, and from a single ungulate on a specific site dispersing the same plants through both endo- and fur-epizoochory. Here, overlap and complementarity are understood in terms of plant species diversity dispersed between ungulates and between dispersal mechanisms, though other components of the SDE (Table 1) such as seed load and distances traveled are also relevant. We carried out a systematic literature review on internal and external ungulate-mediated dispersal processes across worldwide with the following search string in ISI Web of Science (July 9th, 2018).

$T S=$ (Ungulate $^{*}$ OR Artiodactyl ${ }^{*}$ OR Perissodactyl ${ }^{*}$ OR Ruminant* OR Antilocapridae OR Bovidae OR Camelidae OR Cervidae OR Equidae OR Giraffidae OR Hippopotamidae OR Moschidae OR Rhinocerotidae OR Suidae OR Tapiridae OR Tayassuidae OR Tragulidae OR [Genus of all different ungulate species]) $A N D$ TS $=\left(\right.$ Seed $^{*}$ OR endo*zoochor* OR ecto* zoochor* OR epi*zoochor* OR exo*zoochor* OR regurgitation OR frugivor* OR zoochor*) AND TS $=\left(\right.$ Plant $^{*}$ OR invasive* OR exotic ${ }^{*}$ or introduced or non-native*).

The list of all different ungulate genera was retrieved from www.ultimateungulate.com.

We then used basic functional traits (feeding regime and fur characteristics, Albert et al., 2015a,b) to check if we can predict how sympatric ungulates provide overlapping or complementary endozoochorous or epizoochorous dispersal services. We proceeded similarly to predict the overlap and complementarity between endozoochory and fur-epizoochory.

This search provided 22 studies (corresponding to 27 datasets) for endozoochory where at least two ungulate vectors were considered on the same site (i.e., some studies referred to multiple sites and different ungulate communities and were handled as distinct datasets, Table 3). For fur-epizoochory, we retrieved only six studies (corresponding to 7 datasets, Table 4), mainly in Europe. For both endo- and fur-epizoochory combined, we retrieved 17 datasets from 12 studies (i.e., studies including endoand fur-epizoochory for two ungulate vectors were considered as distinct datasets, Table 5). All the retrieved studies and extracted data are included in Tables 3-5.

Most of the studies on ungulate-mediated dispersal retrieved from this search by ungulate community mentioned two or three co-occurring ungulates-studies with 2 ungulates: 11 and 5 for endozoochory and fur-epizoochory, respectively; with 3 ungulates: 12 and 2, respectively (Tables 3, 4). Studies on ungulate endozoochory (Table 3) involving more than three ungulates were rare (e.g., Sigwela, 2004; Young, 2012; Jaroszewicz 


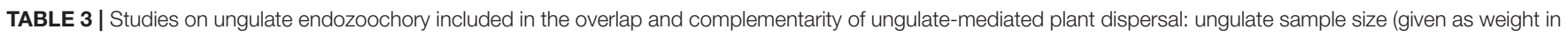
grams or as number of fecal samples), publication, location (site, country), total number of plant species dispersed, \% of plant species dispersed by 2 vectors or more, and germination period ${ }^{*}$ indicates studies where diaspores were identified under a magnifying glass and not after seedling emergence).

\begin{tabular}{|c|c|c|c|c|c|c|}
\hline $\begin{array}{l}\text { Ungulate vectors } \\
\text { (sample size) }\end{array}$ & Publication & Site, country & $\begin{array}{l}\text { Total number of } \\
\text { plant species } \\
\text { dispersed }\end{array}$ & $\begin{array}{l}\% \text { of plant species } \\
\text { dispersed by } 2 \\
\text { vectors (number of } \\
\text { plant species) }\end{array}$ & $\begin{array}{l}\% \text { of plant species } \\
\text { dispersed by }>2 \\
\text { vectors (number of } \\
\text { plant species) }\end{array}$ & $\begin{array}{l}\text { Germination } \\
\text { period (in } \\
\text { months) }\end{array}$ \\
\hline
\end{tabular}

\section{European bison (46), elk Jaroszewicz et al., Białowieza Forest, \\ (35), red deer (80), roe deer $2013 \quad$ Poland}

(33), wild pig (90)

Fallow deer (104), red deer Malo and Suárez, 1995 Castillo de Vinuelas

(103), cattle (104)

Red/fallow deer (235),

(225)

Red deer (105), roe deer Karimi et al., 2018

(48), wild pig (77)

Red deer (77), wild pig (72), Karimi et al., 2018

wild goat (70)

Cattle (20), elk (20), Bartuszevige and

mule/white-tailed deer (10) Endress, 2008

Cattle (10), horse (10), Mouissie et al., 2005b

sheep (10)

, Milton and Dean, 2001 North \& West

goat (19), sheep (49),

donkey (1), eland (200 g),

gemsbok (100 g), giraffe

(400 g), duiker (159),

rhebuck (100 g), kudu (225),

springbok (1), wildebeest

(100 g)

Red deer (60), roe deer (60), Picard et al., $2016 \quad$ Lorris, France wild pig (60)

Zebra (na), eland (na), wildebeest (na)

Shiponeni and Milton, EPNR, South Africa

Muntjac (173), roe deer 2006

(126), red/fallow deer (54)

Chamois (61), red deer

Panter and Dolman, England, UK

2012

(106), wild pig (45), sheep

Young, 2012

Arthurs Pass NP, New

Zealand

191

102

100

species)

$28.80 \%(55)$

$25.13 \%(48)$

36

02

$30.39 \%(31)$

$38.24 \%(39)$

10

Thetfort Forest,

Hyrcanian forest,

NP, Iran

Golestan NP, Iran

Oregon, USA

81

52

52

49

48

provinces, South Africa

Middleton and Mason, Keoladeo NP,

1992

Rajasthan, India

Nilgai (100), cattle (100),

wild pig (100)

Sigwela, 2004

kudu (na), bushbuck (na),

Eastern Cape, South

Africa

goat (na), duiker (na),

grysbok (na)

Gazelle (100), oryx (194), Polak et al., 2014

wild ass (84)

Bushpig (119), bushbuck Castley et al., 2001

(103), grysbok (19)

Donkey (87), goat (88)

Treitler et al., 2017

Benthien et al., 2016

Sheep (10), goat (6)

Red deer (190), wild pig (87) Lepková et al. (2018)

Cattle (4), konik horse (7) Cosyns et al., 2005

Cattle (4), Shetland horse Cosyns et al., 2005 (19)
Negev desert, Israel

$A C D$, South Africa

Sardinia, Italy

Luebeck, Germany

Bohemia, Czech

Republic

Westhoek North,

Belgium

Westhoek South, Belgium
46

$21.74 \%(10)$

$25.58 \%(11)$

$12.20 \%(5)$

$11.76 \%(4)$

$16.00 \%(4)$

$26.09 \%(6)$

63

$22.73 \%(5)$

$12.50 \%(2)$

43.36\% (49)

$17.53 \%(17)$

$35.00 \%$ (28)

$79.10 \%$ (53)

$87.30 \%(55)$
$25.00 \%(25)$

$19.77 \%(17)$

$29.63 \%(24)$

$40.38 \%(21)$

$30.61 \%(15)$

$27.08 \%(13)$

$14.58 \%(7)$

$8.70 \%(4)$

$20.93 \%(9)$

$29.27 \%(12)$

$8.82 \%(3)$

$36.00 \%$ (9)

$21.74 \%(5)$
$4.55 \%(1)$

$-$

$-$

$-$

$-$
$6.25 \%(1)$
0*

12

12

$>2$

36

12

13

$0^{*}$

6

0 *

12

6

6 
TABLE 3 | Continued

\begin{tabular}{|c|c|c|c|c|c|c|}
\hline $\begin{array}{l}\text { Ungulate vectors } \\
\text { (sample size) }\end{array}$ & Publication & Site, country & $\begin{array}{l}\text { Total number of } \\
\text { plant species } \\
\text { dispersed }\end{array}$ & $\begin{array}{l}\% \text { of plant species } \\
\text { dispersed by } 2 \\
\text { vectors (number of } \\
\text { plant species) }\end{array}$ & $\begin{array}{l}\% \text { of plant species } \\
\text { dispersed by }>2 \\
\text { vectors (number of } \\
\text { plant species) }\end{array}$ & $\begin{array}{l}\text { Germination } \\
\text { period (in } \\
\text { months) }\end{array}$ \\
\hline $\begin{array}{l}\text { Fallow deer }(3,728 \mathrm{~g}) \text {, wild } \\
\text { pig }(3,942 \mathrm{~g})\end{array}$ & Heinken et al., 2001 & Kraemer, Germany & 50 & $36.00 \%(18)$ & - & 6 \\
\hline Cattle (14), sheep (15) & Mitlacher et al., 2002 & Öland, Sweden & 45 & $46.67 \%(21)$ & - & 4 \\
\hline Urial (70), gazelle (70) & Karimi et al., 2018 & $\begin{array}{l}\text { Steppe, Golestan NP, } \\
\text { Iran }\end{array}$ & 32 & $31.25 \%(10)$ & - & 15 \\
\hline $\begin{array}{l}\text { Roe deer (152 g), wild pig } \\
(2,448 \mathrm{~g})\end{array}$ & Heinken et al., 2001 & Breiselang, Germany & 25 & $12.00 \%(3)$ & - & 6 \\
\hline Roe deer (60), wild pig (60) & Picard et al., 2016 & Montargis, France & 15 & $20.00 \%(3)$ & - & 12 \\
\hline $\begin{array}{l}\text { Philippine deer (20), feral pig } \\
\text { (31) }\end{array}$ & Gawel et al., 2018 & $\begin{array}{l}\text { Guam, Mariana Islands, } \\
\text { USA }\end{array}$ & 10 & $30 \%(3)$ & - & 15 \\
\hline
\end{tabular}

Na: unavailable information.

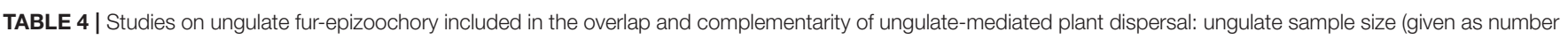
of brushed individuals), publication, location (site, country), total number of plant species dispersed, \% of plant species dispersed by 2 vectors or more.

\begin{tabular}{|c|c|c|c|c|c|}
\hline $\begin{array}{l}\text { Ungulate vectors } \\
\text { (sample size) }\end{array}$ & Publication & Site, country & $\begin{array}{l}\text { Total number of plant } \\
\text { species dispersed }\end{array}$ & $\begin{array}{c}\% \text { of plant species } \\
\text { dispersed by } 2 \text { vectors } \\
\text { (number of plant species) }\end{array}$ & $\begin{array}{c}\% \text { of plant species } \\
\text { dispersed by }>2 \text { vectors } \\
\text { (number of plant species) }\end{array}$ \\
\hline $\begin{array}{l}\text { Cattle (125), } \\
\text { donkey (46), } \\
\text { horse (30) }\end{array}$ & Couvreur et al., 2004 & Flanders, Belgium & 75 & $25.33 \%(19)$ & $14.67 \%(11)$ \\
\hline $\begin{array}{l}\text { Red deer (5), roe } \\
\text { deer(16), } \\
\text { wild pig (6) }\end{array}$ & $\begin{array}{l}\text { Picard and Baltzinger, } \\
2012\end{array}$ & Lorris, France & 18 & $5.56 \%(1)$ & $5.56 \%(1)$ \\
\hline $\begin{array}{l}\text { Goat (17), } \\
\text { sheep (3) }\end{array}$ & $\begin{array}{l}\text { Shmida and Ellner, } \\
1983\end{array}$ & Har Gilo, Israel & 57 & $38.60 \%(22)$ & - \\
\hline $\begin{array}{l}\text { Roe deer (25), wild } \\
\text { pig (9) }\end{array}$ & $\begin{array}{l}\text { Heinken and } \\
\text { Raudnitschka, } 2002\end{array}$ & Breiselang, Germany & 55 & $40.00 \%(22)$ & - \\
\hline $\begin{array}{l}\text { Roe deer (41), wild } \\
\text { pig (25) }\end{array}$ & Schmidt et al., 2004 & $\begin{array}{l}\text { Herzogtum Lauenburg } \\
\text { and } \\
\text { Luechow-Dannenberg, } \\
\text { Germany }\end{array}$ & 42 & $30.95 \%(13)$ & - \\
\hline $\begin{array}{l}\text { Sheep (10), } \\
\text { goat (6) }\end{array}$ & Benthien et al., 2016 & Luebeck, Germany & 38 & $28.95 \%(11)$ & - \\
\hline $\begin{array}{l}\text { Roe deer (7), wild } \\
\text { pig (11) }\end{array}$ & $\begin{array}{l}\text { Picard and Baltzinger, } \\
2012\end{array}$ & Montargis, France & 29 & $6.90 \%(2)$ & - \\
\hline
\end{tabular}

et al., 2013), though one study mentioned up to 13 ungulates in South Africa (Milton and Dean, 2001). Second, most of the studies involved wild ungulates; and domestic ungulates were mentioned more rarely (Mitlacher et al., 2002; Cosyns et al., 2005; Mouissie et al., 2005b; Benthien et al., 2016; and Treitler et al., 2017, Table 3).

\section{Endozoochory by at Least Two Ungulates}

In its "foliage is the fruit hypothesis," Janzen (1984) proposed different predictions. The first one states that [...] herbaceous plant vegetation is edible to several large herbivores [...]. The review we made confirms this first prediction as we showed that co-occurring ungulates dispersed at least two similar plant species in each considered study. Indeed, we revealed a systematic overlap when two ungulates are present at a site, with both ungulate species dispersing between $11.76 \%$ (Young, 2012) and $87.30 \%$ (Cosyns et al., 2005) of the total number of plant species dispersed (Table 3). These proportions correspond to two (Castley et al., 2001) to a maximum of 55 plant species (Cosyns et al., 2005; Jaroszewicz et al., 2013). This pattern is reinforced when we consider studies where at least three ungulates are present. In these cases, again a significant proportion of all the plant species dispersed are dispersed by three ungulates or more. This proportion ranges from 4.55\% (Polak et al., 2014) to 38.24\% (Malo and Suárez, 1995) of the total number of plants dispersed (Table 3) and corresponds to one (Castley et al., 2001; Polak et al., 2014) to a maximum of 48 plant species (Jaroszewicz et al., 2013). These results demonstrate 


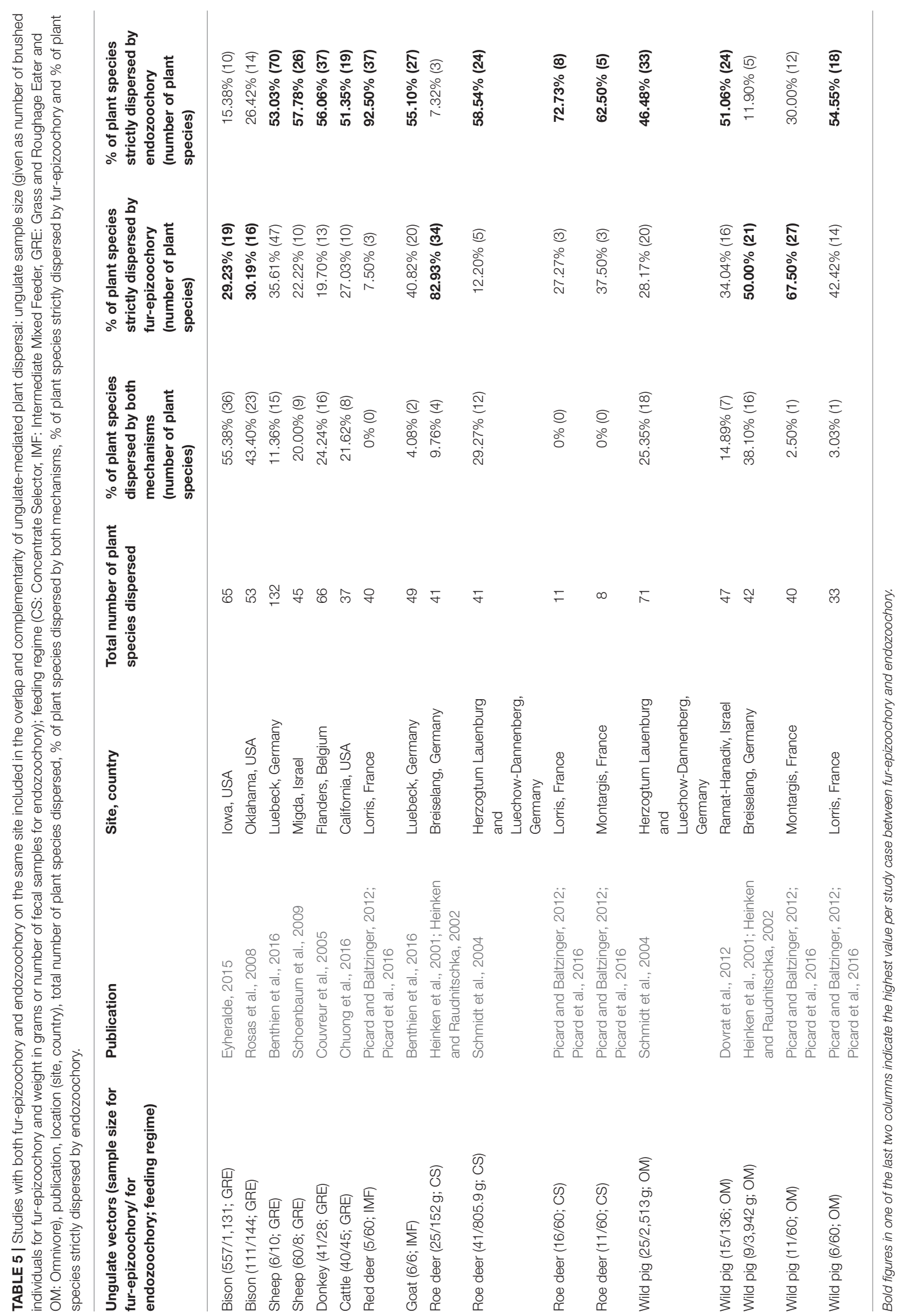


that some plant species can rely on different co-occurring ungulates. At the same time, other plant species are solely dispersed by a single vector species. In this case, ungulates provide complementary dispersal services at the scale of the plant community.

Further, we assessed all combinations of two ungulates ( $n$ $=98$ cases, Table 6) from the datasets retrieved (ungulate endozoochory, Table 3) and we summarized the proportion of plant species dispersed, taking into account the feeding regime of each ungulate (Hofmann, 1989; Hempson et al., 2015). The sample size of each combination varies between four (a Grass and Roughage Eater with an Omnivore) and eighteen (a Grass and Roughage Eater with an Intermediate Mixed Feeder, Table 6). Combinations of two Grass and Roughage Eaters $(n=9)$ shared the highest number of plant species dispersed, nearly $50 \%$, whereas for all other combinations of different feeding regimes, this proportion ranged from $10 \%$ (two Concentrate Selectors) to $25 \%$ (a Grass and Roughage Eater with an Omnivore) and showed high variability (Table 6).

\section{Fur-Epizoochory by at Least Two Ungulates}

We used the same approach to evaluate the six studies retrieved on fur-epizoochory (Table 4). Couvreur et al. (2004) mentioned a maximum of 75 plant species dispersed by three domestic ungulates (cattle, donkey, and horse) whereas Picard and Baltzinger (2012) found 18 plant species dispersed by three wild ungulates: red deer, roe deer and wild pig. Here again, we revealed a systematic overlap when two ungulates are present at a site, with both ungulate species dispersing between $5.56 \%$ (one plant species, Picard and Baltzinger, 2012) and $40 \%$ (22 plant species, Heinken and Raudnitschka, 2002) of the total number of plant species dispersed (Table 4). When we consider studies where at least three ungulates are present, again a significant proportion of all the plant species dispersed are dispersed by three ungulates. This proportion ranges from $5.56 \%$ (one plant species, Picard and Baltzinger, 2012) to $14.67 \%$ (11 plant species, Couvreur et al., 2004) of the total number of plants dispersed (Table 4).

Further, we assessed all combinations of two ungulates from the datasets retrieved (ungulate fur-epizoochory, Table 4) and we summarized the proportion of plant species dispersed, taking into account two fur characteristics (hair length and curliness, as described by Albert et al., 2015b). Fur-epizoochory provided many fewer comparisons ( $n=11$ cases for each characteristic, Table 6); therefore, our results must be carefully interpreted and considered to be mere trends. The highest shared number of plant species dispersed systematically involved a curled-haired ungulate (between 26 and $34 \%$ of shared plant species dispersed) or the presence of one long-haired ungulate (between 21 and $30 \%$ of shared plant species dispersed, Table 6).

\section{Complementarity of Fur-Epizoochory and Endozoochory}

The last part of this section is dedicated to the complementarity of the two main ungulate-mediated dispersal mechanisms, furepizoochory and endozoochory. We retrieved 17 cases where both mechanisms were studied for at least one ungulate on a specific site, 12 cases involving different wild ungulates (roe deer, red deer, American bison, Bison bison, and wild pig) and 5 cases involving domestic ungulates (goat, sheep, Ovis aries, donkey and cattle) (Table 5; Figure 3). We have seen that the temporal dynamics of the seed release varies with the ungulate species and the dispersal mechanisms (Figure 2) with implications for plant dispersal distances. The extreme number of plants dispersed by a domestic ungulate vary between 37 (cattle, Chuong et al., 2016) and 132 (sheep, Benthien et al., 2016) different plant species dispersed through endozoochory and/or fur-epizoochory (Table 5). If we consider wild ungulates, the total number of plant species dispersed ranges between 8 (roe deer, Picard and Baltzinger, 2012; Picard et al., 2016) and 71 (wild pig, Schmidt et al., 2004, Table 5). No plant species was dispersed through both mechanisms by roe deer or red deer in France (Picard and Baltzinger, 2012; Picard et al., 2016), whereas American bison displayed the highest number of plant species dispersed through both endo- and fur-epizoochory with 36 different plant species, representing more than $55 \%$ of the total number of plant species dispersed (Eyheralde, 2015). Roe deer $(n=4)$, the single Concentrate Selector and wild pig $(n=5)$, the single Omnivore, are the most frequently studied ungulates. They disperse variable numbers of plant species, ranging between 8 and 41 for roe deer, and between 33 and 71 for wild pig (Schmidt et al., 2004; Picard and Baltzinger, 2012; Picard et al., 2016). We can take a similar picture if we consider the proportion of plant species dispersed by endo- and fur-epizoochory, ranging between $0 \%$ and nearly $30 \%$ for Concentrate Selectors (here, roe deer), and between 2.5 to $38 \%$ for Omnivores (here, wild pig, Table 5). Concerning Grass and Roughage Eaters $(n=6$, including American bison, cattle, donkey and sheep), and especially American bison, a significant proportion (nearly $30 \%$ ) of the dispersed plant species are dispersed both externally and internally. Intermediate Mixed Feeders ( $n=2$, red deer and goat) dispersed both externally and internally the lowest proportion plant species (Figure 3). Finally, among the 17 study cases reviewed and whatever the ungulate species concerned, 12 study cases report higher number of plant species strictly dispersed by endozoochory in comparison with 5 study cases by fur-epizoochory.

\section{PERSPECTIVES}

\section{Methodological Challenges}

First, we would like to again underline the limitations involved in comparing the available studies on ungulate-mediated endozoochory in the literature. There are still no standardized criteria applied to the samples for either germination conditions (e.g., closed vs. open greenhouses; greenhouse vs. natural conditions) or abiotic conditions (e.g., controlled vs. fluctuating temperatures; with or without irrigation). Even the length of the germination experiments differed greatly amongst the studies (see Table 3). Generally, at least one full year is advised to assess germination success and identify the plant species, but Young (2012) and Jaroszewicz et al. (2013) prolonged that period for up to 3 years. Notably, Jaroszewicz et al. (2013) showed that Yellow Star of Bethlehem (Gagea lutea), an ancient forest species, 
TABLE 6 | Proportion of shared dispersed plant species for different combinations of feeding regimes (CS: Concentrate Selector, IMF: Intermediate Mixed Feeder, GRE: Grass and Roughage Eater and OM: Omnivore) for endozoochory (left columns) and hair characteristics (hair curliness: curly, wavy and straight; hair length: short, medium and long as described in Albert et al., 2015b) for fur-epizoochory (right columns).

\begin{tabular}{|c|c|c|c|}
\hline \multicolumn{2}{|c|}{ Endozoochory } & \multicolumn{2}{|c|}{ Fur-epizoochory } \\
\hline Feeding regimes (sample size) & $\begin{array}{l}\% \text { of shared dispersed plant } \\
\text { species (mean } \pm 95 \% \mathrm{Cl} \text { ) }\end{array}$ & Hair characteristics (sample size) & $\begin{array}{l}\% \text { of shared dispersed plant } \\
\text { species (mean } \pm 95 \% \mathrm{Cl})\end{array}$ \\
\hline GRE-GRE $(n=9)$ & $47.44 \pm 10 \%$ & curly-wavy $(n=2)$ & $33.77 \pm 10 \%$ \\
\hline GRE-IMF $(n=18)$ & $17.43 \pm 6 \%$ & curly-straight $(n=2)$ & $26.67 \pm 10 \%$ \\
\hline GRE-CS $(n=16)$ & $12.89 \pm 6 \%$ & wavy-wavy $(n=1)$ & $5.56 \%$ \\
\hline GRE-OM $(n=4)$ & $25.34 \pm 19 \%$ & wavy-straight $(n=5)$ & $18.9 \pm 13 \%$ \\
\hline IMF-IMF $(n=6)$ & $12.93 \pm 14 \%$ & straight-straight $(n=1)$ & $16.00 \%$ \\
\hline IMF-CS $(n=17)$ & $16.05 \pm 7 \%$ & long-medium $(n=6)$ & $21.09 \pm 12 \%$ \\
\hline IMF-OM $(n=10)$ & $16.15 \pm 11 \%$ & long-short $(n=3)$ & $29.63 \pm 10 \%$ \\
\hline $\operatorname{CS}-\operatorname{CS}(n=9)$ & $10.26 \pm 9 \%$ & medium-medium $(n=1)$ & $5.56 \%$ \\
\hline CS-OM $(n=9)$ & $19.64 \pm 12 \%$ & medium-short $(n=1)$ & $16.00 \%$ \\
\hline
\end{tabular}

Bold figures show highest values.

only germinated in European bison dungs during the third year of the experiment. They further observed that some seedlings emerged up to 7 years after the beginning of the experiment. Time for germination of ungulate-dispersed seeds is rarely reported (but see Milotić and Hoffmann, 2016c). The application of average germination conditions might not fit the germination requirements of each of the diaspores present in the feces. One solution might be to check each seed for viability (tetrazolium test). However, this method only indicates the intrinsic ability of a seed to germinate while the abiotic conditions at the release site might not fit its germination requirements; such a viability test could easily lead to an over-estimation of germination success. Pakeman and Small (2009) showed that the germination success under natural conditions was lower than in greenhouses. In three of the retrieved studies on endozoochory (Table 3), dispersed seeds were morphologically identified and submitted neither to seedling emergence nor to viability test (Castley et al., 2001; Sigwela, 2004 and Benthien et al., 2016).

Fur-epizoochory and regurgitation need to be studied in much greater depth, and in association with endozoochory on the same sites and within communities of ungulates (Table 3). Future research should also focus on plant dispersal networks involving ungulates and other taxa of dispersal agents to help addressing the relative importance of ungulates as plant dispersal agents (e.g., Fedriani and Delibes, 2009).

\section{Overlap and Complementarity of Ungulate-Mediated Dispersal Services for Habitat Restoration}

The results from our systematic literature review enable us to provide preliminary recommendations concerning ungulates as potential tools for habitat restoration, thanks to their dispersal services. At the landscape scale, dispersal agents with the highest overlap in dispersed plant species between them might replace one another to some extent, while those with the least overlap provide a complementary service. When choosing appropriate dispersal vectors to be included in the management or restoration of a landscape (i.e., rewilding concept), the total amount of plant species and diaspores dispersed by a given ungulate should be a selection criterion for consideration (e.g., sheep, Rico et al., 2014). Grass and Roughage Eaters, thanks to their diversified feeding regime, disperse a large amount of different plant species. They are also the most similar vectors when more than one ungulate species of this same feeding regime co-occur; this is even true when we compare different dispersal processes, like endozoochory and fur-epizoochory. Consequently, if the aim is to restore degraded habitats, managers of natural areas should consider introducing or re-introducing complementary ungulates and at least one of the following species: sheep, cattle or bison. Associating a Grass and Roughage Eater, efficient for quantitative dispersal, with an ungulate from a different feeding regime (Concentrate Selector or Omnivore) for qualitative dispersal would create a beneficial complementarity in the restoration program.

Fur-epizoochory highlights the overlapping plant dispersal services of long- and curly-haired ungulates with other ungulates. Sheep would again offer effective dispersal services. Rico et al. (2014) demonstrated that rotational shepherding might be useful in restoring plant communities. Wild pigs are likely to offer contradictory services, being an effective epizoochorous dispersal agent but also a potential consumer of the seeds.

\section{Research Perspectives}

In a recent paper, John et al. (2016) have called for researchers to include the role of animal cognition on plant-animal interactions such as seed dispersal, herbivory and pollination. Animal memory can lead to directed dispersal: animals may select specific plants at specific places and release them at predictable safe resting places. Richard et al. (2014) provided quantitative proof of temporal home range fidelity for ungulates like red and roe deer and, Riotte-Lambert et al. (2017) developed a framework for the study of routine movement behavior. Similarly, taking animal behavior (Russo et al., 2006), and animal sociality (Sarasa et al., 2009; Liehrmann et al., 2018) into account will open new research 


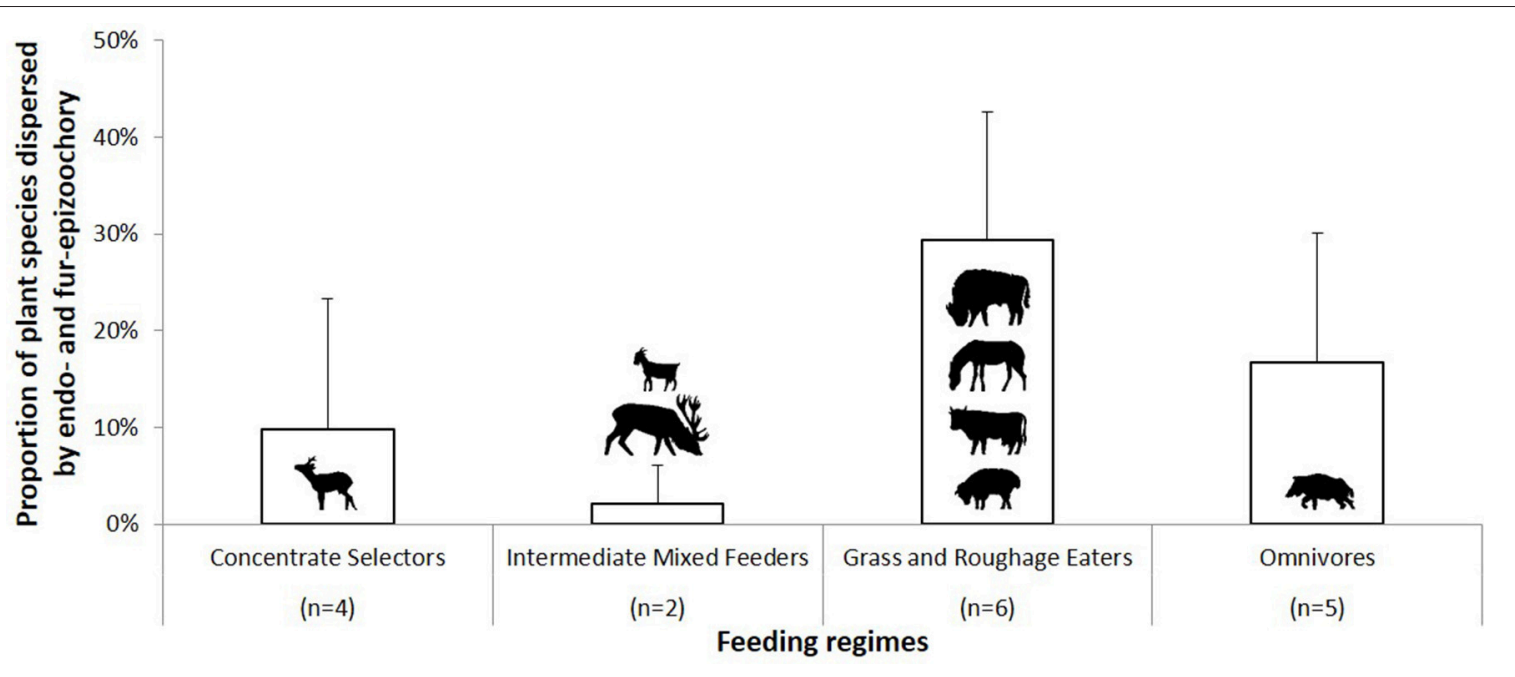

FIGURE 3 | Proportion of plant species dispersed through endozoochory and fur-epizoochory by ungulates according to their feeding regime (Table 5). Concentrate Selectors are represented by roe deer (Capreolus capreolus); Intermediate Mixed Feeders by goat (Capra aegagrus hircus) and red deer (Cervus elaphus); Grass and Roughage Eaters by American bison (Bison bison), donkey (Equus asinus), cattle (Bos taurus), and sheep (Ovis aries) and Omnivores by wild pig (Sus scrofa).

opportunities for the further investigation of ungulate-mediated plant dispersal. Though this may be challenging in closed forest environments, one could start by matching behavioral observations of ungulates mainly dwelling in open areas, for instance reindeer in mountainous areas (Mårell et al., 2002) or mountain ibex in alpine grasslands, with the study of plant dispersal. The use of acceleration sensors (Nams, 2014; Kröschel et al., 2017) and its calibration with control animals will help determine activity (active vs. resting) and specific behaviors (e.g., lying, feeding, walking, trotting) of the equipped animals together with its location in open or closed habitats. This could render more realistic the study of the transfer phase of ungulatemediated dispersal that generally combines retention times and associated distances traveled (Westcott et al., 2005; Pellerin et al., 2016). Wang and Smith (2002) proposed new techniques to the study of seed dispersal among which stable isotope ratios and molecular genetic markers to link dispersed seeds to parent plants. More recent applications of genetic tools to seed dispersal allow the identification of the disperser (DNA barcoding) and relate dispersed seeds to parent plants (DNA microsatellites, González-Varo et al., 2017). They could be used for guild of ungulate dispersers.

We found very few studies on mountain ungulate communities (but see Young, 2012 for New Zealand alpine ecosystems and Karimi et al., 2018, for North-Eastern Iran), whereas ungulate contribution to altitudinal plant dispersal should be investigated. Bertrand et al. (2011) showed that mountain plant communities coped with climatic changes better than did lowland communities. Rumpf et al. (2018) also used vegetation resampling to assess temporal changes of lower and upper range limits of a set of plants of the European Alps, but dispersal-related traits failed to explain the upward movement of the plants. However, these traits were computed from data obtained on lowland ungulates (Mouissie et al., 2005a;
Römermann et al., 2005) probably inappropriate in mountainous areas. Following this, further studies are required to ascertain and quantify the role of mountain ungulates like chamois, mouflon or mountain ibex, especially in relation to plant response to climate change in alpine ecosystems.

Recent studies have stressed the implication of native, domestic and introduced ungulates in the dispersal of exotic plants. Some researchers have found that native ungulates aid the spread of exotic invasive plants (Myers et al., 2004; Vavra et al., 2007; Eschtruth and Battles, 2009) as Schiffman (1997) suggested. But, how do the traits of these exotic invasives compared to those of native plants in terms of ungulate-mediated dispersal? Preliminary observations tend to show that some exotic plants occupy a complementary feeding niche (i.e., phenological shift) for large herbivores by offering green edible material when the rest of the vegetation is dry. This is the case for instance for the leaves and fruits of tickberry (Lantana camara) consumed by giraffes (Giraffa camelopardalis), nyalas (Tragelaphus angasii), and zebras (Equus burchelli) in South Africa during austral winter.

In addition to being dispersal agents, these large herbivores mediate plant-plant interactions and modify the local abiotic conditions where diaspores are released, through nutrient fluxes (white-tailed deer; Seagle, 2003) and physical disturbance (repeated rooting or scraping). They thus create windows of opportunity for plants to establish (Myster, 1993). Ungulates also interact with other taxa, both animal (earthworms, Dávalos et al., 2015) and plant (shrubs, Boulanger et al., 2018), for the recruitment of forest plants. Finally, few studies have formally demonstrated the role ungulates in long distance plant dispersal (Vickery et al., 1986); most studies use indirect approaches (Boulanger et al., 2011; Milotić et al., 2017). To conclude, large strides have been made despite methodological 
constraints in the direct measurement of dispersal by large ungulates. However, one fundamental question still remains, i.e., what is the proportion of diaspores produced by a given plant that are carried over long distances by large ungulates? Addressing this question will help us to gain a deeper understanding of the full range of effects ungulates have in an ecosystem.

\section{AUTHOR CONTRIBUTIONS}

$\mathrm{CB}$ proposed the idea and led the writing. SK provided data and commented on the content of the manuscript. US and CB equally contributed to the systematic literature review. $\mathrm{CB}, \mathrm{SK}$, and US all contributed to the re-reading of the manuscript.

\section{FUNDING}

US is currently working under a $\mathrm{PhD}$ grant from Irstea and Center-Val de Loire Region (2015-00099650, Costaud project).

\section{REFERENCES}

Abbas, F., Merlet, J., Morellet, N., Verheyden, H., Hewison, A. J. M., Cargnelutti, B., et al. (2012). Roe deer may markedly alter forest nitrogen and phosphorus budgets across Europe. Oikos 121, 1271-1278. doi: 10.1111/j.1600-0706.2011.20103.x

Albert, A., Auffret, A. G., Cosyns, E., Cousins, S. A. O., D’hondt, B., Baltzinger, C., et al. (2015a). Seed dispersal by ungulates as an ecological filter: a trait-based meta-analysis. Oikos 124, 1109-1120. doi: 10.1111/oik.02512

Albert, A., Mårell, A., Picard, M., and Baltzinger, C. (2015b). Using basic plant traits to predict ungulate seed dispersal potential. Ecography 38, 440-449. doi: $10.1111 /$ ecog.00709

Bartuszevige, A. M., and Endress, B. A. (2008). Do ungulates facilitate native and exotic plant spread? Seed dispersal by cattle, elk and deer in northeastern Oregon. J. Arid Environ. 72, 904-913. doi: 10.1016/j.jaridenv.2007.11.007

Benthien, O., Bober, J., Castens, J., and Stolter, C. (2016). Seed dispersal capacity of sheep and goats in a near-coastal dry grassland habitat. Basic Appl. Ecol. 508-515. doi: 10.1016/j.baae.2016.03.006

Bertrand, R., Lenoir, J., Piedallu, C., Riofrio-Dillon, G., De Ruffray, P., Vidal, C., et al. (2011). Changes in plant community composition lag behind climate warming in lowland forests. Nature 479, 517-520. doi: 10.1038/nature10548

Bohême, C. (2012). Diaspore Transport in the fur of Wild Ungulates: Which Traits Facilitate Epizoochory? [French]. Master of Science dissertation, Jean Monnet University, Saint Etienne.

Boulanger, V., Baltzinger, C., Saïd, S., Ballon, P., Ningre, F., Picard, J. F., et al. (2011). Deer-mediated expansion of a rare plant species. Plant Ecol. 212, 307-314. doi: 10.1007/s11258-010-9823-9

Boulanger, V., Baltzinger, C., Saïd, S., Ballon, P., Picard, J.-F., and Dupouey, J.-L. (2009). Ranking temperate woody species along a gradient of browsing by deer. Forest Ecol. Manage. 258, 1397-1406. doi: 10.1016/j.foreco.2009.06.055

Boulanger, V., Dupouey, J.-L., Archaux, F., Badeau, V., Baltzinger, C., Chevalier, R., et al. (2018). Ungulates increase forest plant species richness to the benefit of non-forest specialists. Global Change Biol. 24, e485-e495. doi: $10.1111 /$ gcb.13899

Bruun, H. H., and Poschlod, P. (2006). Why are small seeds dispersed through animal guts: large numbers or seed size per se? Oikos 113, 402-411. doi: 10.1111/j.2006.0030-1299.14114.x

Bullock, J. M., Galsworthy, S., Manzano, P., Poschlod, P., Eichberg, C., Walker, K., et al. (2011). Process-based functions for seed retention on animals: A test of improved descriptions of dispersal using multiple data sets. Oikos 120, 1201-1208. doi: 10.1111/j.1600-0706.2010.19092.x
SK benefitted from a 3-month exchange grant at Irstea in spring 2017 from the University of Isfahan, Iran. CB benefitted from a 2month research fellowship funded by the Center of Excellence for Invasion Biology in Stellenbosch, the French Embassy in Pretoria and the MiDi Thematic Research Network in Center-Val de Loire Region.

\section{ACKNOWLEDGMENTS}

Final discussions on this review project occurred during a workshop organized in July 2018 (Pietermaritzburg, South Africa) involving Stellenbosch University, the University of KwaZulu-Natal in Pietermaritzburg and SAN Parks. We also thank our European colleagues (listed in Albert et al., 2015a) from the informal network on ungulate-mediated seed dispersal for discussions at different steps that fed the content of this manuscript. We are grateful to Marie Baltzinger for her drawings. We would like to thank the two reviewers and the associate editor who helped us improve the first version of this manuscript, Victoria Moore and US for proofreading the English manuscript.

Côté, S. D., Rooney, T. P., Tremblay, J.-P., Dussault, C., and Waller, D. M. (2004). Ecological impacts of deer overabundance. Ann. Rev. Ecol. Evol. Syst. 35, 113-147. doi: 10.1146/annurev.ecolsys.35.021103.105725

Castañeda, I., Fedriani, J. M., and Delibes, M. (2017). Potential of red deer (Cervus elaphus) to disperse viable seeds by spitting them from the cud. Mammal. Biol. 90, 89-91. doi: 10.1016/j.mambio.2017.10.004

Castley, J. G., Bruton, J.-S., Kerley, G. I. H., and Mclachlan, A. (2001). The importance of seed dispersal in the Alexandria Coastal Dunefield, South Africa. J. Coast. Conserv. 7, 57-70. doi: 10.1007/BF02742468

Cederlund, G. N. (1989). Activity patterns in moose and roe deer in a north boreal forest. Holartic Ecol. 12, 39-45. doi: 10.1111/j.1600-0587.1989.tb00820.x

Chuong, J., Huxley, J., Spotswood, E. N., Nichols, L., Mariotte, P., and Suding, K. N. (2016). Cattle as dispersal vectors of invasive and introduced plants in a california annual grassland. Rangeland Ecol. Manage. 69, 52-58. doi: 10.1016/j.rama.2015.10.009

Clauss, M., Fritz, J., Bayer, D., Nygren, K., Hammer, S., Hatt, J.-M., et al. (2009). Physical characteristics of rumen contents in four large ruminants of different feeding type, the addax (Addax nasomaculatus), bison (Bison bison), red deer (Cervus elaphus) and moose (Alces alces). Compar. Biochem. Physiol. A Mol. Integr. Physiol. 152, 398-406. doi: 10.1016/j.cbpa.2008.11.009

Clauss, M., Schwarm, A., Ortmann, S., Streich, W. J., and Hummel, J. (2007). A case of non-scaling in mammalian physiology? Body size, digestive capacity, food intake, and ingesta passage in mammalian herbivores. Compar. Biochem. Physiol. A Mol. Integr. Physiol. 148, 249-265. doi: 10.1016/j.cbpa.2007.05.024

Cornelis, J., Casaer, J., and Hermy, M. (1999). Impact of season, habitat and research techniques on diet composition of roe deer (Capreolus capreolus): a review. J. Zool. 248, 195-207. doi: 10.1111/j.1469-7998.1999.tb01196.x

Cosyns, E., Claerbout, S., Lamoot, I., and Hoffmann, M. (2005). Endozoochorous seed dispersal by cattle and horse in a spatially heterogeneous landscape. Plant Ecol. 178, 149-162. doi: 10.1007/s11258-004-2846-3

Couvreur, M., Christiaen, B., Verheyen, K., and Hermy, M. (2004). Large herbivores as mobile links between isolated nature reserves through adhesive seed dispersal. Appl. Veg. Sci. 7, 229-236. doi: 10.1111/j.1654-109X.2004.tb00614.x

Couvreur, M., Cosyns, E., Hermy, M., and Hoffmann, M. (2005). Complementarity of epi- and endozoochory of plant seeds by free ranging donkeys. Ecography 28, 37-48. doi: 10.1111/j.0906-7590.2005.04159.x

Cransac, N., Cibien, C., Angibault, J.-M., Morellet, N., Vincent, J.-P., and Hewison, A. J. M. (2001). Seasonal and sex-related variations in forest roe deer (Capreolus capreolus) diet (Dourdan forest). Mammalia 65, 1-12. doi: 10.1515/mamm.2001.65.1.1 
Dávalos, A., Nuzzo, V., and Blossey, B. (2015). Interactive effects of deer, earthworms and non-native plants on rare forest plant recruitment. Biol. Conserv. 187, 173-181. doi: 10.1016/j.biocon.2015.04.025

Delibes, M., Casta-eda, I., and Fedriani, J. M. (2017). Tree-climbing goats disperse seeds during rumination. Front. Ecol. Environ. 15, 222-223. doi: 10.1002/fee.1488

D'hondt, B., Bossuyt, B., Hoffmann, M., and Bonte, D. (2008). Dung beetles as secondary seed dispersers in a temperate grassland. Basic Appl. Ecol. 542-549. doi: 10.1016/j.baae.2007.11.002

Dovrat, G., Perevolotsky, A., and Ne'eman, G. (2012). Wild boars as seed dispersal agents of exotic plants from agricultural lands to conservation areas. J. Arid Environ. 78, 49-54. doi: 10.1016/j.jaridenv.2011.11.011

Dugger, P. J., Blendinger, P. G., Böhning-Gaese, K., Chama, L., Correia, M., Dehling, D. M., et al. (2018). Seed-dispersal networks are more specialized in the Neotropics than in the Afrotropics. Global Ecol. Biogeogr. 28, 248-261. doi: 10.1111 /geb.12833

Eschtruth, A. K., and Battles, J. J. (2009). Acceleration of exotic plant invasion in a forested ecosystem by a generalist herbivore. Conserv. Biol. 23, 388-399. doi: 10.1111/j.1523-1739.2008.01122.x

Eycott, A. E., Watkinson, A., Hemami, M.-R., and Dolman, P. (2007). The dispersal of vascular plants in a forest mosaic by a guild of mammalian herbivores. Oecologia 154, 107-118. doi: 10.1007/s00442-007-0812-1

Eyheralde, P. G. (2015). Bison-Mediated Seed Dispersal in a Tallgrass Prairie Reconstruction. Doctoral dissertation, Iowa State University, USA.

Fedriani, J. M., and Delibes, M. (2009). Seed Dispersal in the Iberian pear, Pyrus bourgaeana: a role for infrequent mutualists. Ecoscience 16, 311-321. doi: $10.2980 / 16-3-3253$

Feer, F. (1995). Seed dispersal in African forest ruminants. J. Trop. Ecol. 11, 683-689. doi: 10.1017/S0266467400009238

Fischer, S. F., Poschlod, P., and Beinlich, B. (1996). Experimental studies on the dispersal of plants and animals on sheep in calcareous grasslands. J. Appl. Ecol. 33, 1206-1222. doi: 10.2307/2404699

Galetti, M., and Dirzo, R. (2013). Ecological and evolutionary consequences of living in a defaunated world. Biol. Conserv. 163, 1-6. doi: 10.1016/j.biocon.2013.04.020

Gawel, A. M., Rogers, H. S., Miller, R. H., and Kerr, A. M. (2018). Contrasting ecological roles of non-native ungulates in a novel ecosystem. Royal Soc. Open Sci. 5:170151. doi: 10.1098/rsos.170151

Gebert, C., and Verheyden-Tixier, H. (2001). Variations of diet composition of red deer (Cervus elaphus L.) in Europe. Mammal Rev. 31, 189-201. doi: 10.1046/j.1365-2907.2001.00090.x

González-Varo, J. P., Carvalho, C. S., Arroyo, J. M., and Jordano, P. (2017). Unravelling seed dispersal through fragmented landscapes: frugivore species operate unevenly as mobile links. Mol. Ecol. 26, 4309-4321. doi: $10.1111 / \mathrm{mec} .14181$

Groves, C., and Grubb, P. (2011). Ungulate taxonomy. Baltimore, MD: The Johns Hopkins University Press.

Heinken, T., Hanspach, H., Raudnitschka, D., and Schaumann, F. (2002). Dispersal of vascular plants by four species of wild mammals in a deciduous forest in NE Germany. Phytocoenologia 32, 627-643. doi: 10.1127/0340-269X/2002/0032-0627

Heinken, T., Hanspach, H., and Schaumann, F. (2001). Welche Rolle spielt die endozoochore Ausbreitung von Pflanzen durch wildlebende Säugetiere? Untersuchungen in zwei brandenburgischen Waldgebieten. Hercynia 34, 237-259.

Heinken, T., and Raudnitschka, D. (2002). Do wild ungulates contribute to the dispersal of vascular plants in central European forests by epizoochory? A case study in NE Germany. Forstwissenschaftliches Centralblatt 121, 1-19. doi: 10.1046/j.1439-0337.2002.02029.x

Heinken, T., Schmidt, M., Von Oheimb, G., Kriebitzsch, W.-U., and Ellenberg, H. (2006). Soil seed banks near rubbing trees indicate dispersal of plant species into forests by wild boar. Basic Appl. Ecol. 7, 31-44. doi: 10.1016/j.baae.2005.04.006

Hempson, G. P., Archibald, S., and Bond, W. J. (2015). A continent-wide assessment of the form and intensity of large mammal herbivory in Africa. Science 350, 1056-1061. doi: 10.1126/science.aac7978

Hofmann, R. R. (1989). Evolutionary steps of ecophysiological adaptation and diversification of ruminants: a comparative view of their digestive system. Oecologia 78, 443-457. doi: 10.1007/BF00378733
Illius, A. W., and Gordon, I. J. (1992). Modelling the nutritional ecology of ungulate herbivores: evolution of body size and competitive interactions. Oecologia 89, 428-434. doi: 10.1007/BF00317422

Jabot, F., Etienne, R. S., and Chave, J. (2008). Reconciling neutral community models and environmental filtering: theory and an empirical test. Oikos 117, 1308-1320. doi: 10.1111/j.0030-1299.2008.16724.x

Janzen, D. H. (1984). Dispersal of small seeds by big herbivores: foliage is the fruit. Am. Nat. 123, 338-353. doi: 10.1086/284208

Jaroszewicz, B. (2013). Endozoochory by European bison influences the build-up of the soil seed bank in subcontinental coniferous forest. Eur J Forest Res. 132, 445-452. doi: 10.1007/s10342-013-0683-4

Jaroszewicz, B., Piroznikow, E., and Sondej, I. (2013). Endozoochory by the guild of ungulates in Europe's primeval forest. Forest Ecol. Manage. 305, 21-28. doi: 10.1016/j.foreco.2013.05.004

Johansson, A. (2000). Effect of roe buck removal on marking intensity. Acta Theriol. 45, 123-128. doi: 10.4098/AT.arch.00-13

John, E. A., Soldati, F., Burman, O. H. P., Wilkinson, A., and Pike, T. W. (2016). Plant ecology meets animal cognition: impacts of animal memory on seed dispersal. Plant Ecol. 217, 1441-1456. doi: 10.1007/s11258-016-0652-3

Jones, C. G., Lawton, J. H., and Shachak, M. (1994). Organisms as ecosystem engineers. Oikos 69, 373-386. doi: 10.2307/3545850

Jordano, P. (2000). "Fruits and Frugivory," in Seeds: The Ecology of Regeneration in Plant Communities, 2nd edn, ed M. Fenner (Wallingford: CABI Publ.), 125-166

Karimi, S., Hemami, M. R., Esfahani, M. T., Akhani, H., and Baltzinger, C. (2018). Complementary endozoochorous seed dispersal by large mammals in the Golestan National Park, Iran. Seed Sci. Res. 28, 294-302. doi: 10.1017/S0960258518000351

Keuling, O., Stier, N., and Roth, M. (2008). Annual and seasonal space use of different age classes of female wild boar Sus scrofa L. Eur. J. Wildlife Res. 54, 403-412. doi: 10.1007/s10344-007-0157-4

Kowalczyk, R., Taberlet, P., Coissac, E., Valentini, A., Miquel, C., Kaminski, T., et al. (2011). Influence of management practices on large herbivore diet-Case of European bison in Białowieza Primeval Forest (Poland). Forest Ecol. Manage. 261, 821-828. doi: 10.1016/j.foreco.2010.11.026

Kraft, N. J. B., Adler, P. B., Godoy, O., James, E. C., Fuller, S., and Levine, J. M. (2015). Community assembly, coexistence and the environmental filtering metaphor. Funct. Ecol. 29, 592-599. doi: 10.1111/1365-2435.12345

Kröschel, M., Reineking, B., Werwie, F., Wildi, F., and Storch, I. (2017). Remote monitoring of vigilance behavior in large herbivores using acceleration data. Anim. Biotelem. 5:10. doi: 10.1186/s40317-017-0125-z

Latham, J., Staines, B. W., and Gorman, M. L. (1999). Comparative feeding ecology of red (Cervus elaphus) and roe deer (Capreolus capreolus) in Scottish plantation forests. J. Zool. 247, 409-418. doi: 10.1111/j.1469-7998.1999.tb01003.x

Le Corre, M., Pellerin, M., Pinaud, D., Van Laere, G., Fritz, H., and Saïd, S. (2009). A multi-patch use of the habitat: testing the first-passage time analysis on roe deer Capreolus capreolus paths. Wildlife Biol. 14, 339-349. doi: 10.2981/09096396(2008)14[339:AMUOTH]2.0.CO;2

Lefcort, H., and Pettoello, C. L. (2012). White-tailed deer trails are associated with the spread of exotic forbs. Nat. Areas J. 32, 159-165. doi: 10.3375/043.032.0204

Lepková, B., Horčičková, E., and Vojta, J. (2018). Endozoochorous seed dispersal by free-ranging herbivores in an abandoned landscape. Plant Ecol. 219, 1127-1138. doi: 10.1007/s11258-018-0864-9

Liehrmann, O., Jégoux, F., Guilbert, M.-A., Isselin-Nondedeu, F., Saïd, S., Locatelli, Y., et al. (2018). Epizoochorous dispersal by ungulates depends on fur, grooming and social interactions. Ecol. Evol. 8, 1582-1594. doi: 10.1002/ece3.3768

Loison, A., Gaillard, J. M., Pélabon, C., and Yoccoz, N. G. (1999). What factors shape sexual size dimorphism in ungulates? Evol. Ecol. Res. 1, 611-633.

Mårell, A., Ball, J. P., and Hofgaard, A. (2002). Foraging and movement paths of female reindeer: Insights from fractal analysis, correlated random walks, and Lévy flights. Can. J. Zool. 80, 854-865. doi: 10.1139/z02-061

Malo, J. E., and Suárez, F. (1995). Herbivorous mammals as seed dispersers in a Mediterranean dehesa. Oecologia 104, 246-255. doi: 10.1007/BF00328589

Mandujano, S., Gallina, S., and Bullock, S. H. (1994). Frugivory and dispersal of Spondias purpurea (Anacardiaceae) in a tropical deciduous forest in México. Int. J. Trop. Biol. Conserv. 42, 107-114. 
Mc Alpine, C., Catterall, C. P., Nally, R. M., Lindenmayer, D., Reid, J. L., Holl, K. D., et al. (2016). Integrating plant- and animal-based perspectives for more effective restoration of biodiversity. Front. Ecol. Environ. 14, 37-45. doi: 10.1002/16-0108.1

Mc Conkey, K. R., Prasad, S., Corlett, R. T., Campos-Arceiz, A., Brodie, J. F., Rogers, H., et al. (2012). Seed dispersal in changing landscapes. Biol. Conserv. 146, 1-13. doi: 10.1016/j.biocon.2011.09.018

Middleton, B. A., and Mason, D. H. (1992). Seed herbivory by nilgai, feral cattle, and wild boar in the Keoladea-National-Parl, India. Biotropica 24, 538-543. doi: $10.2307 / 2389017$

Miguel, M. F., Jordano, P., Tabeni, S., and Campos, C. M. (2018). Contextdependency and anthropogenic effects on individual plant-frugivore networks. Oikos 127, 1045-1059. doi: 10.1111/oik.04978

Milotić, T., Baltzinger, C., Eichberg, C., Eycott, A. E., Heurich, M., Müller, J., Hoffmann, M. et al. (2018). Dung beetle assemblages, dung removal and secondary seed dispersal: data from a large-scale multi-site experiment in the Western Palaearctic. Front. Biogeogr. 10, 1-15. doi: 10.21425/F5101-237289

Milotić, T., Baltzinger, C., Eichberg, C., Eycott, A. E., Heurich, M., Müller, J., Hoffmann, M., et al. (2019). Functionally richer communities improve ecosystem functioning: dung removal and secondary seed dispersal by dung beetles in the Western Palaearctic. J. Biogeogr. 46, 70-82. doi: 10.1111/jbi. 13452

Milotić, T., and Hoffmann, M. (2016a). Cost or benefit for growth and flowering of seedlings and juvenile grassland plants in a dung environment. Plant Ecol. 217, 1025-1042. doi: 10.1007/s11258-016-0629-2

Milotić, T., and Hoffmann, M. (2016b). How does gut passage impact endozoochorous seed dispersal success? Evidence from a gut environment simulation experiment. Basic Appl. Ecol. 17, 165-176. doi: 10.1016/j.baae.2015.09.007

Milotić, T., and Hoffmann, M. (2016c). Reduced germination success of temperate grassland seeds sown in dung: consequences for post-dispersal seed fate. Plant Biol. 18 1038-1047. doi: 10.1111/plb.12506

Milotić, T., Suyoto, H. N., Provoost, S., and Hoffmann, M. (2017). Herbivoreinduced expansion of Helianthemum nummularium in grassland-scrub mosaic vegetation: circumstantial evidence for zoochory and indirect grazing impact. Plant Ecol. 218, 867-884. doi: 10.1007/s11258-017-0736-8

Milton, S. J., and Dean, W. R. J. (2001). Seeds dispersed in dung of insectivores and herbivores in semi-arid southern Africa. J. Arid Environ. 47, 465-483. doi: 10.1006/jare.2000.0727

Mitlacher, K., Poschlod, P., Rosen, E., and Bakker, J. P. (2002). Restoration of wooded meadows-a comparative analysis along a chronosequence on Oland (Sweden). Appl. Veg. Sci. 5, 63-73. doi: 10.1111/j.1654-109X.2002.tb00536.x

Mouissie, A. M., Van Der Ween, C. E. J., Veen, G. F. C., and Van Diggelen, R. (2005a). Ecological correlates of seed survival after ingestion by Fallow Deer. Funct. Ecol. 19, 284-290. doi: 10.1111/j.0269-8463.2005.00955.x

Mouissie, A. M., Vos, P., Verhagen, H. M. C., and Bakker, J. P. (2005b). Endozoochory by free-ranging, large herbivores: ecological correlates and perspectives for restoration. Basic Appl. Ecol. 6, 547-558. doi: 10.1016/j.baae.2005.03.004

Murray, B. D., Webster, C. R., and Bump, J. K. (2013). Broadening the ecological context of ungulate-ecosystem interactions: the importance of space, seasonality, and nitrogen. Ecology 94, 1317-1326. doi: 10.1890/12-1582.1

Myers, J. A., Vellend, M., Gardescu, S., and Marks, P. L. (2004). Seed dispersal by white-tailed deer: implications for long-distance dispersal, invasion, and migration of plants in eastern North America. Oecologia 139, 35-44. doi: 10.1007/s00442-003-1474-2

Myster, R. W. (1993). Tree invasion and establishment in old fields at hutchesonmemorial-forest. Botan. Rev. 59, 251-272. doi: 10.1007/BF02857418

Nams, V. O. (2014). Combining animal movements and behavioural data to detect behavioural states. Ecol. Lett. 17, 1228-1237. doi: 10.1111/ele.12328

Newton, P. N. (1989). Associations between langur monkeys (Presbytis entellus) and chital deer (Axis axis): chance encounters or a mutualism? Ethology 83, 89-120. doi: 10.1111/j.1439-0310.1989.tb00522.x

Pakeman, R. J. (2001). Plant migration rates and seed dispersal mechanisms. J. Biogeogr. 28, 795-800 doi: 10.1046/j.1365-2699.2001.00581.x

Pakeman, R. J., Digneffe, G., and Small, J. L. (2002). Ecological correlates of endozoochory by herbivores. Funct. Ecol. 16, 296-304. doi: 10.1046/j.1365-2435.2002.00625.x
Pakeman, R. J., and Small, J. L. (2009). Potential and realised contribution of endozoochory to seedling establishment. Basic Appl. Ecol. 10, 656-661. doi: 10.1016/j.baae.2009.03.007

Panter, C. J., and Dolman, P. M. (2012). Mammalian herbivores as potential seed dispersal vectors in ancient woodland fragments. Wildlife Biol. 18, 292-303. doi: 10.2981/11-112

Pellerin, M., Picard, M., Saïd, S., Baubet, E., and Baltzinger, C. (2016). Complementary endozoochorous long-distance seed dispersal by three native herbivorous ungulates in Europe. Basic Appl. Ecol. 17, 321-332. doi: 10.1016/j.baae.2016.01.005

Pépin, D., Renaud, P.-C., Dumont, B., and Decuq, F. (2006). Time budget and 24h temporal rest-activity patterns of captive red deer hinds. Appl. Anim. Behav. Sci. 101, 339-354. doi: 10.1016/j.applanim.2006.02.002

Picard, M., and Baltzinger, C. (2012). Hitch-hiking in the wild: should seeds rely on ungulates? Plant Ecol. Evol. 145, 24-30. doi: 10.5091/plecevo.2012.689

Picard, M., Chevalier, R., Barrier, R., Boscardin, Y., and Baltzinger, C. (2016). Functional traits of seeds dispersed through endozoochory by native forest ungulates. J. Veg. Sci. 27, 987-998. doi: 10.1111/jvs. 12418

Picard, M., Papaïx, J., Gosselin, F., Picot, D., Bideau, E., and Baltzinger, C. (2015). Temporal dynamics of seed excretion by wild ungulates: implications for plant dispersal. Ecol. Evol. 5, 2621-2632. doi: 10.1002/ece3. 1512

Polak, T., Gutterman, Y., Hoffman, I., and Saltz, D. (2014). Redundancy in seed dispersal by three sympatric ungulates: a reintroduction perspective. Anim. Conserv. 17, 565-572. doi: 10.1111/acv.12122

Prasad, S., Krishnaswamy, J., Chellam, R., and Goyal, S. P. (2006). Ruminantmediated seed dispersal of an economically valuable tree in indian dry forests. Biotropica 38, 679-682. doi: 10.1111/j.1744-7429.2006.00182.x

Ramesh, T., Kalle, R., Sankar, K., and Qureshi, Q. (2012). Langur-chital association in Mudumalai Tiger Reserve. Western Ghats: ZOO's PRINT XXVII.

Richard, E., Saïd, S., Hamann, J.-L., and Gaillard, J.-M. (2014). Daily, seasonal, and annual variations in individual home-range overlap of two sympatric species of deer. Can. J. Zool. 92, 853-859. doi: 10.1139/cjz-2014-0045

Rico, Y., Boehmer, H. J., and Wagner, H. H. (2014). Effect of rotational shepherding on demographic and genetic connectivity of calcareous grassland plants. Conserv. Biol. 28, 467-477. doi: 10.1111/cobi.12186

Riotte-Lambert, L., Benhamou, S., and Chamaillé-Jammes, S. (2017). From randomness to traplining: a framework for the study of routine movement behavior. Behav. Ecol. 28, 280-287. doi: 10.1093/beheco/arw154

Römermann, C., Tackenberg, O., and Poschlod, P. (2005). How to predict attachment potential of seeds to sheep and cattle coat from simple morphological seed traits. Oikos 110, 219-230. doi: 10.1111/j.0030-1299.2005.13911.x

Rosas, C. A., Engle, D. M., Shaw, J. H., and Palmer, M. W. (2008). Seed dispersal by Bison bison in a tallgrass prairie. J. Veg. Sci. 19, 769-778. doi: $10.3170 / 2008-8-18447$

Rumpf, S. B., Hülber, K., Klonner, G., Moser, D., Schütz, M., Wessely, J., et al. (2018). Range dynamics of mountain plants decrease with elevation. Proc. Natl. Acad. Sci. 115, 1848-1853. doi: 10.1073/pnas.1713936115

Russo, S. E., Portnoy, S., and Augspurger, C. K. (2006). Incorporating animal behavior into seed dispersal models: implications for seed shadows. Ecology 87, 3160-3174. doi: 10.1890/0012-9658(2006)87[3160:IABISD]2.0.CO;2

Sarasa, M., Serrano, E., Gonzalez, G., Granados, J. E., Soriguer, R. C., Perez, J. M., et al. (2009). Pseudoectoparasites: a new tool for exploring the relationship between host behaviour and ectoparasites. Anim. Behav. 77, 1351-1356. doi: 10.1016/j.anbehav.2009.01.005

Schiffman, P. M. (1997). "Animal-mediated dispersal and disturbance: driving forces behind alien plant naturalization," in Assessment and Management of Plant Invasions, eds. J. O. Luken and J. W. Thieret. (New York, NY: Springer), 87-94.

Schley, L., and Roper, T. J. (2003). Diet of wild boar Sus scrofa in Western Europe, with particular reference to consumption of agricultural crops. Mamm. Rev. 33, 43-56. doi: 10.1046/j.1365-2907.2003.00010.x

Schmidt, M., Sommer, K., Kriebitzsch, W. U., Ellenberg, J. H., and Oheimb, G.V. (2004). Dispersal of vascular plants by game in northern Germany. Part I: roe deer (Capreolus capreolus) and wild boar (Sus scrofa). Eur. J. Forest Res. 123, 167-176. doi: 10.1007/s10342-004-0029-3 
Schoenbaum, I., Kigel, J., Barkai, D., and Landau, S. (2009). Weed infestation of wheat fields by sheep grazing stubble in the Mediterranean semi-arid region. Crop Pasture Sci. 60, 675-683. doi: 10.1071/CP08283

Schulze, K. A., Buchwald, R., and Heinken, T. (2014). Epizoochory via the hoovesthe European bison (Bison bonasus L.) as a dispersal agent of seeds in an open-forest-mosaic. Tuexenia 34, 131-143. doi: 10.14471/2014.34.016

Schupp, E. W. (1993). Quantity, quality and the effectiveness of seed dispersal by animals. Plant Ecol. 107-108, 15-29. doi: 10.1007/978-94-011-1749-4_2

Schupp, E. W., Jordano, P., and Gómez, J. M. (2010). Seed dispersal effectiveness revisited: a conceptual review. New Phytol. 188, 333-353. doi: 10.1111/j.1469-8137.2010.03402.x

Schwarm, A., Ortmann, S., Wolf, C., Streich, W. J., and Clauss, M. (2008). Excretion patterns of fluid and different sized particle passage markers in banteng (Bos javanicus) and pygmy hippopotamus (Hexaprotodon liberiensis): two functionally different foregut fermenters. Compar. Biochem. Physiol. A Mol. Integr. Physiol. 150, 32-39. doi: 10.1016/j.cbpa.2008.02.022

Seagle, S. W. (2003). Can ungulates foraging in a multiple-use landscape alter forest nitrogen budgets? Oikos 103, 230-234. doi: 10.1034/j.1600-0706.2003.12287.x

Shiponeni, N. N., and Milton, S. J. (2006). Seed dispersal in the dung of large herbivores: implications for restoration of Renosterveld shrubland old fields. Biodiver. Conserv. 15, 3161-3175. doi: 10.1007/s10531-0056317-5

Shmida, A., and Ellner, S. (1983). Seed dispersal on pastoral grazers in open mediterranean chaparral, Israel. Israel. J. Botany 32, 147-159.

Sigwela, A. M. (2004). Animal Seed Interactions in the Thicket Biome: Consequences of Faunal Replacements and Land Use for Seed Dynamics. Doctoral dissertation, University of Port Elizabeth, South Africa.

Sobral-Souza, T., Lautenschlager, L., Morcatty, T. Q., Bello, C., Hansen, D., and Galetti, M. (2017). Rewilding defaunated Atlantic Forests with tortoises to restore lost seed dispersal functions. Perspect. Ecol. Conserv. 15, 300-307. doi: 10.1016/j.pecon.2017.08.005

Sridhara, S., Mc Conkey, K., Prasad, S., and Corlett, R. T. (2016). "Frugivory and seed dispersal by large herbivores of Asia," in The Ecology of Large Herbivores in South and Southeast Asia, eds. F. S. Ahrestani and M. Sankaran. (Dordrecht: Springer Science+Business Media), 121-150. doi: 10.1007/978-94-017-7570-0_5

Steuer, P., Südekum, K. H., Müller, D. W. H., Franz, R., Kaandorp, J., Clauss, M., et al. (2011). Is there an influence of body mass on digesta mean retention time in herbivores? A comparative study on ungulates. Compar. Biochem. Physiol. Mol. Integrat. Physiol. 160, 355-364. doi: 10.1016/j.cbpa.2011. 07.005

Torn, A., Siikamaki, P., and Tolvanen, A. (2010). Can horse riding induce the introduction and establishment of alien plant species through endozoochory and gap creation? Plant Ecol. 208, 235-244. doi: 10.1007/s11258-009-9701-5

Treitler, J. T., Drissen, T., Stadtmann, R., Zerbe, S., and Mantilla-Contreras, J. (2017). Complementing endozoochorous seed dispersal patterns by donkeys and goats in a semi-natural island ecosystem. BMC Ecol. 17:42. doi: 10.1186/s12898-017-0148-6
Vander Wall, S. B., and Longland, W. S. (2004). Diplochory: are two seed dispersers better than one? Trends Ecol. Evol. 19, 155-161. doi: 10.1016/j.tree.2003.12.004

Vavra, M., Parks, C. G., and Wisdom, M. J. (2007). Biodiversity, exotic plant species, and herbivory: the good, the bad, and the ungulate. For. Ecol. Manage. 246, 66-72. doi: 10.1016/j.foreco.2007.03.051

Vellend, M., Knight, T. M., and Drake, J. M. (2006). Antagonistic effects of seed dispersal and herbivory on plant migration. Ecol. Lett. 9, 319-326. doi: 10.1111/j.1461-0248.2005.00878.x

Vickery, R. K., Phillips, D. R., and Wonsavage, P. R. (1986). Seed dispersal in mimulus-guttatus by wind and deer. Am. Midland Natural. 116, 206-208. doi: $10.2307 / 2425954$

Wang, B. C., and Smith, T. B. (2002). Closing the seed dispersal loop. Trends Ecol. Evol. 17, 379-386. doi: 10.1016/S0169-5347(02)02541-7

Welander, J. (2000). Spatial and Temporal Dynamics of a Disturbance Regime: Wild Boar (Sus scrofa L.) Rooting and its Effects on Plant Species Diversity. Doctoral dissertation, Swedish University of Agricultural Sciences, Uppsala.

Wells, F. H., and Lauenroth, W. K. (2007). The potential for horses to disperse alien plants along recreational trails. Rangel. Ecol. Manage. 60, 574-577. doi: 10.2111/06-102R1.1

Wenny, D. G. (2001). Advantages of seed dispersal: a re-evaluation of directed dispersal. Evol. Ecol. Res. 3, 51-74.

Westcott, D. A., Bentrupperbäumer, J., Bradford, M. G., and Mckeown, A. (2005). Incorporating patterns of disperser behaviour into models of seed dispersal and its effects on estimated dispersal curves. Oecologia 146, 57-67. doi: 10.1007/s00442-005-0178-1

Wilby, A., Shachak, M., and Boeken, B. (2001). Integration of ecosystem engineering and trophic effects of herbivores. Oikos 92:436. doi: 10.1034/j.1600-0706.2001.920305.x

Williams, S. C., and Ward, J. S. (2006). Exotic seed dispersal by white-tailed deer in Southern Connecticut. Nat. Areas J. 26, 383-390. doi: 10.3375/08858608(2006)26[383:ESDBWD]2.0.CO;2

Wilson, D. E., and Reeder, D. M. (2005). Mammal Species of the World: A Taxonomic and Geographic Reference, $3 r d$ Edn. Baltimore: MD.

Young, L. M. (2012). Seed Dispersal Mutualisms and Plant Regeneration in New Zealand Alpine Ecosystems. Doctoral dissertation, University of Canterbury, New Zealand.

Conflict of Interest Statement: The authors declare that the research was conducted in the absence of any commercial or financial relationships that could be construed as a potential conflict of interest.

Copyright (c) 2019 Baltzinger, Karimi and Shukla. This is an open-access article distributed under the terms of the Creative Commons Attribution License (CC BY). The use, distribution or reproduction in other forums is permitted, provided the original author(s) and the copyright owner(s) are credited and that the original publication in this journal is cited, in accordance with accepted academic practice. No use, distribution or reproduction is permitted which does not comply with these terms. 